\title{
فاعلية استخدام بعض اساليب التدريس على تعلم مهارة الوثب الطويل لتلاميذ المرحلة الابتدائية
}

• احمد عبدالفتاح عبدالعظيم خليفة

مقدمة البحث

المقدمة :

ان العالم فى العصر الحالى يمر بثورة علمية هائلة شملت كل مجالات الحياة من النظور العلمى فلقد تطورت اساليب وطرق التثريس فى الاونة الاخيرة نتيجة لتطور المجتمعات

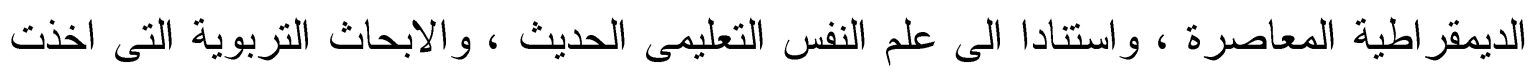
فى الحسبان الازدياد المطرد لوعى المدرسين،وحاجاتهم الى تغير النمط التقليدى فى عملية التعليم،

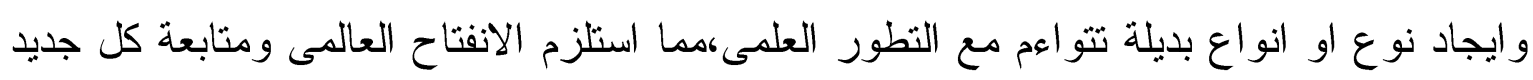

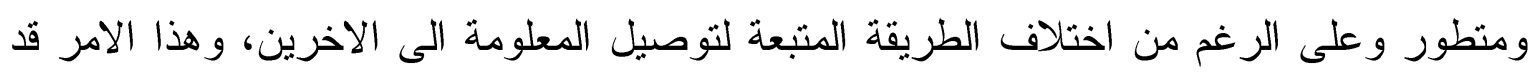

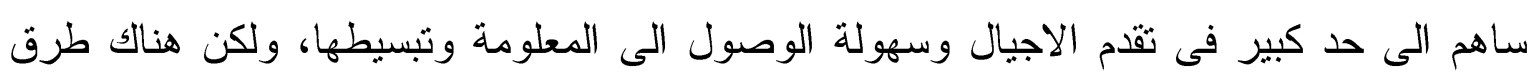

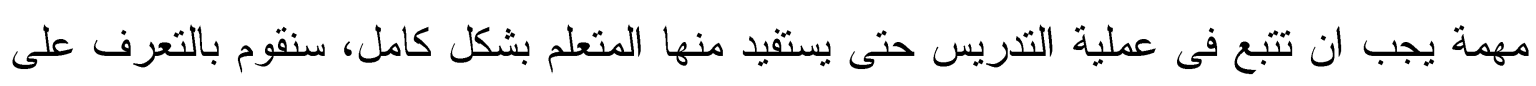
افضل اساليب التدريس الحديثة والمهمة فى المؤسسات التعليمية ومن هذه الاساليب المتطورة

$$
\text { اسلوبى الاكتشاف الموجه وتوجيه الاقران (10 (1). }
$$

على كثرتها وتعددها وقد بذل "بلوم" جهودا ضخمة من اجل التوصل الى استر اتيجية يمكن من خلالها التوصل الى مواجهة الفروق الفردية بين المتعلمين بصورة منهجية منظمة ومنتظمة و انصبت جهوده الاساسية فى البحث عن الية تمكن نسبة كبيرة من الطلاب فى الوصول الى لى لئه

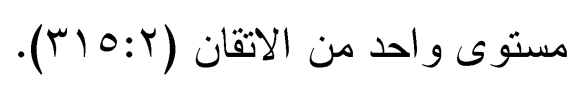

واختلاف طرق التدريس وتعددها امر تفرضه الظروف المختلفة التى تتم فيها العملية

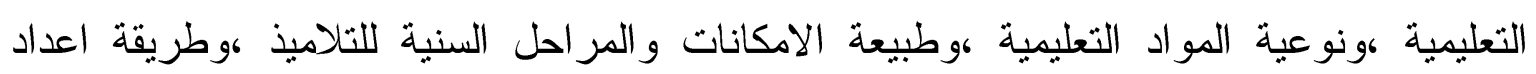
المدرس وصفاته الثخصية التى يتصف بها، الى كثير من المتغيرات التى تستوجب دائما البحث و التجريب وصو لا الى احسن الطرق و الوسائل المناسبة لتدريس الانشطة المختلفة (1: •r (). 
كما يشير سعيد الثاهد (99V) الى ان طرق تدريس التربية الرياضية تحتوى على العديد من طرق التدريس و الاساليب التى تميزها عن العلوم التزبوية الاخرى والتى تهتم بالمتعلم وتهيئة سبل النجاح له مع الاخذ فى الاعتبار ان المعلم هو الركيزة الاساسية فى تحقيق عملية التعلم باختيار اسلوب التثريس بما يناسب المرحلة السنبة (با (1)).

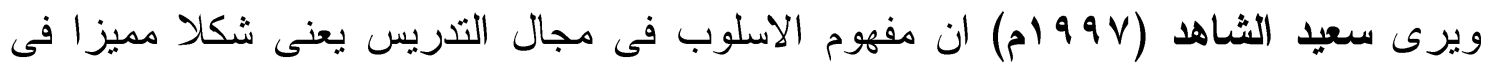
تتفيذ الدرس يتخذه الددرس كوسيلة لتعليم التلاميذ وقد يتبنى المدرس اسلوب او اكثر وقد يفرض المطلوب تعليمه او المرحلة السنية للتلاميذ استخدام اسلوب خاص يسهل الى وصول المعلومات .$(0 V: 14)$

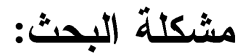

حيث ان الاتجاهات التربوية الحديثة تدعو الى الاهتمام بالمنعلم والعمل على تتمية جميع جو انبه بشكل متكامل ومتزن من الناحية البدنية و المهارية و النفسية والمعرفية،كما انها تدعو الى الاهتمام بالمتعلم ليصبح جزءا اساسيا وفعالا فى العملية التعليمية،وان يكون دوره ايجابيا بدلا من ان يكون متلقى للمعلومات والقائمون على العطلية التعليمية يحاولون الوصول الى تحقيق الهذف و الغاية من العملية التعليمية بدرجة عالية من الكفاءة والاتقان،وان يعبر المتعلم عن ذاتيته فى العملية التعليمية ولذلك فهى تر اعى الفرد المتعلم وحاجاته وميوله وهى بهذا التطويرتحاول تحقيق الاهداف المنشودة من العملية التعليمية (r:1).

ان مسابقات العاب القوى بمسابقاتها المختلفة سواء فى المضمار او الميدان من الرياضات الاساسية التى تكسب الثباب اللياقة البدنية العالية، فضلا عن انها تعمل على تتمية الفرد بدنيا وخاقيا ونفسيا وهى اصل الالعاب الاولمبية القديمة و الحديثة لتنوع وتعدد مسابقاتها، كما انها تعد مقياسا لتقدم ورقى الدول لكثرة مسابقاتها وعدد المشتركين فيها من متسابقين وحكام ومنظمين و اداريين ومساعدين وعاما بانها تتناسب مع مختلف الاعمار و الجنسين وتقام فى ملاعب مكثوفة ومغطاه و على مدار السنة (0ب:0 10). 
ان مسابقات العاب القوى تحتوى على حركات الانسان الطبيعية والتى تثتمل على الجرى و الوثب والدفع وتثكل هذه الدسابقات الجزء الاكبر والرئيسى من الالعاب الاولمبية الحديثة $\cdot(I V: r \cdot)$

ومسابقات العاب القوى من الانشطة الرياضية التى تتطلب مو اصفات وقدرات واستعدادت خاصة لاى المتعلمين فى درس التربية الرياضية وخاصة مسابقة الوثب الطويل والتى شهدت تطور ا ملحوظا فى الاونة الاخيرة سو اء فى طرق ادائها او ارقامها القياسية او فى قدرة المتعلمين على النهوض بالمستوى الرقمى والمستوى الفنى للاداء وتطويره من خلال الدورات و البطو لات مماجعل كثير من الباحثين والمعلمين يهتمون بدرجة كبيرة بتطبيق بعض الاساليب الحديثة و استخدام بعض التمرينات و التدريبات المتطورة فى تعليم مسابقات العاب القوى بصفة عامة .

وتعتبر مسابقة الوثب الطويل من أقدم المسابقات في ألعاب القوى ، وهي عبارة عن حركة

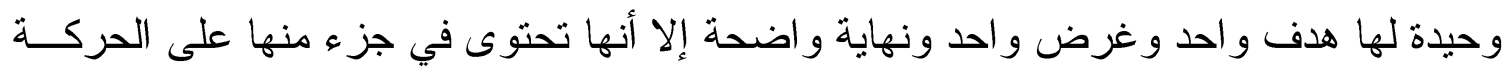

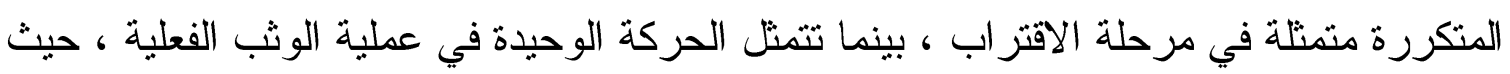

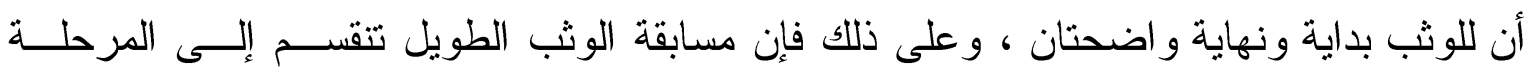

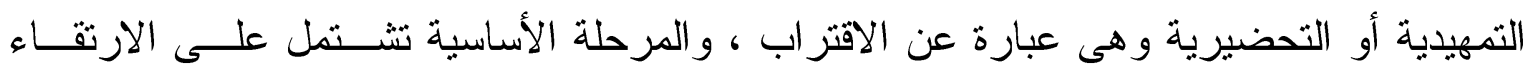

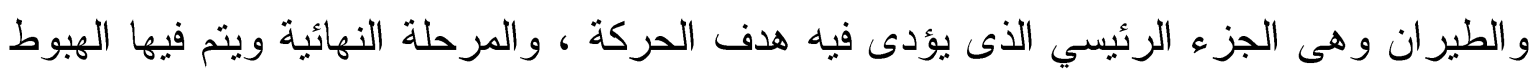
$(1 \leq: 1 \wedge)$.

ومع ظهور النظريات التربوية الحديثة التى تتادى بالاهتمام بالطالب ومشاركته فى العملية التعليمية والاهتمام بالتفاعل مع المعلم وتلاميذه وبين التلاميذ والمادة التعليمية او الخبرات التربوية اصبحت المسئولية الاولى والاساسية للمعلم تتمثل فى العمل على تتظيم المو اقف التعليمية وتوجيه تلاميذه للقيام بالنشاط اللازم لتحقيق الاهداف المنشودة (^: • r).

وفى مجال التربية الرياضية قدمت مجموعة من اساليب التعلم الخاصة بتعليم المهارات الحركية وتم حصر المراجع والدراسات التى تتاولت اساليب التدريس وقد تم اختيار بعض الاساليب (اسلوب توجيه الاقران- اسلوب الاكتثاف الموجه) كاحد اساليب التدريس الحديثة فى تعلم مهار ات العاب القوى فى المدارس. 


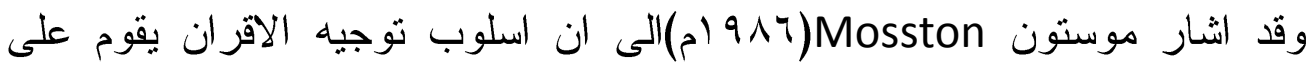
تنظيم المجموعة الدراسية فى شكل ثنائيات من التلاميذ بحيث يعطى لكل تلميذ دور محدد فيقوم تلميذ معين بدور المؤدى، ويقوم الاخر بدور الملاحظ، اما المؤدى يقوم بنادية المهمة، ويقوم الملاحظ بتوفير التخذية الر اجعة اللازمة بناءا على معايير معينة يعطيها المعلم بصورة مسبقة وبعد الانتهاء من العملية التعليمية يتبادل التلاميذ الادوار(المؤدى - الملاحظ)،وقد اشارت العديد من الخبرات ان لهذا الاسلوب تاثير ا كبير ا على نمو التلاميذ من الناحية الاجتماعية والانفعالية ومن ناحية اخرى يمكن ان يسهم فى النمو المعرفى للتلاميذ هذا بالاضافة لارتفاع مستوى الاداء

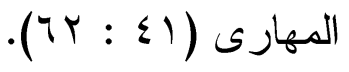

ومن ناحية اخرى اثارت عفاف عبد الكريم (ع99 ام) ان اسلوب توجيه الاقران تظهر فائدته فى المر احل الاولى من تعلم المهارة عندما يحتاج التلاميذ الى التعرف على قدر ات هامة بعد كل محاولة لتساعدهم على تصحيح ادائهم الفنى ويعتبر بمثابة توفير مدرس لكل تلميذ (9 (1) 11 (1). وبالرغم من النطور الذى يحدث فى مناهج واساليب التنريس فى التربية البدنية الا ان الاسلوب المستخدم فى تعليم مسابقات العاب القوى بصفة عامة ومسابقة الوثب الطويل بصفة خاصة هو الاسلوب المعتمد اعتمادا كليا على المعلم فى العملية التعليمية والذى ينم من خلاله الالقاء و الثرح اللفظى و اعطاء نموذج و الذى يكون فيه دور المتعلم سلبيا ولم يتغير هذا الاسلوب منذ سنوات هذا بالاضافة الى ضعف اداء التلاميذ فى مسابقة الوثب الطويل وعزوفهم عن الاشتراك فى هذه المسابقة بالاضافة الى ان اعداد التلاميذ اصبحت كثيرة جدا فى مدارسنا فى عصرنا الحاضركل هذه العو امل السابقة تؤدى الى عدم مقدرة المدرس على الاشر اف على جميع التلاميذ مع استخدام اسلوب التلقين و الشرح من جانب المعلم الامر الذى يعطى الفرصة للمتعلم بتكرار المهارة مما يفقده المشاركة الايجابية وابداء الملاحظات وحرصا على ان تنتقل اساليب التدريس التى تعتمد على سلبية المتعلم الى اساليب منطورة يتفاعل فيها المتعلم مع تعلم المهارت ويكون دوره اكثر ايجابيا وفعالا ونشطا وفضلا على انتقال النواتج التعليمية من المعلم الى المتعلم ويكون دور المعلم فيها هو التوجيه والارشاد و التخطيط للاداء.

ولذا فان الباحث سوف ينعرف على تاثير استخدام بعض اساليب التدريس( اسلوب نوجيه الاقران- اسلوب الاكتشاف الموجه) من خلال تصميم برنامج تعليمى لتعلم مهارة الوثب الطويل 
لاى تلاميذ الحلقة المرحلة الابتدائية محاو لا الارتقاء بالمستوى البدنى و المهارى و الرقمى لديهم فى

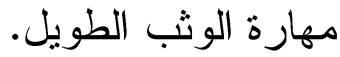

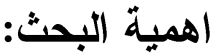

تبرز أهمية البحث و الحاجة اليه وتزداد وضوحا من خلال النقاط التالية : - استخدام بعض اساليب التدريس (اسلوب توجيه الاقران- اسلوب لاكتثاف الموجه ) فى تعلم مهارة الوثب الطويل بدلا من استخدام اسلوب الاو امر .

- محاولة الوصول الى برنامج تعليمى مبنى على اسس علمية لتعلم مسابقة الوثب الطويل. - - محاولة التظلب على الصعوبات التي تواجه المتعلمين عند تعلم الأداء المهاري الوثب الطويل وذلك بإيجاد الأسلوب التعليمي الأكثر فاعلية في التعليم. - - محاولة الارثقاء بمستوى الاداء المهارى و الفنى لدى التلاميذ فى مهارة الوثب الطويل. - محاولة تطوير الصفات البدنية الخاصة و المستوى الرقمى لمهارة الوثب الطويل.

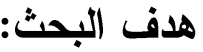

يهذف هذا البحث إلى وضع برنامج تعليمى باستخدام بعض اساليب التدريس ومعرفة تأثيره علي تحسن المستوي الرقمي لمهارة الوثب الطويل لتلاميذ المرحلة الابتدائية .

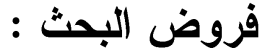

1- توجد فروق دالة احصائيا بين منوسطات القياسات القبلية و البعدية ولصالح القياسات البعدية للمجموعة الضابطة باستخدام اسلوب الاو امر فى تعلم مهارة الوثب الطويل لتلاميذ المرحلة الابتدائية. r- توجد فروق دالة احصائيا بين منوسطات القياسات القبلية و البعدية ولصالح القياسات البعدية للمجموعة التجريبة الاولى باستخدام اسلوب توجيه الاقران فى تعلم مهارة الوثب الطويل

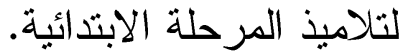
r- توجد فروق دالة احصائبا بين متوسطات القياسات القبلية و البعدية ولصالح القياسات البعدية للمجموعة التجريبة الثانية باستخدام اسلوب التعلم الاكتثاف الموجه فى تعلم مهارة الوثب الطويل لتلاميذ المرحلة الابتدائية. المصطلحات المستخدمة فى البحث: 
"هى مجموعة من اجر اءات التدريس التى يقوم بها القائم بالتدريس مسبقا حيث تعينه على تتفيذ التدريس فى ضوء الامكانات المتاحة لتحقيق الاهداف التنريسية لمنظومة التدريس التى يبنى

$$
\begin{aligned}
& \text { عليها وباقصى فاعلية ممكنة" (س ب: .0). } \\
& \text { اسلوب توجيه الاقران : }
\end{aligned}
$$

"هو ذلك الاسلوب الذى يتم فيه تقسيم الطلاب داخل المجموعة الواحدة الى ازواج للعهـل معا بالتبادل احدها يؤدى والاخر يلاحظ ويكون دور الملاحظ هو تقديم تغذية راجعة بالمعلومات

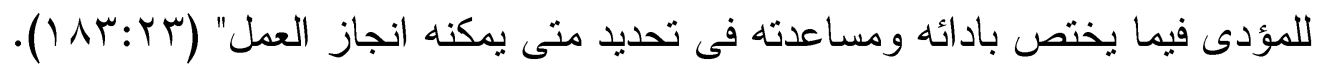

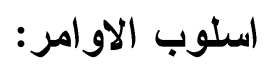

"هو ذللك الاسلوب الذى يعرض محتو اه الكلى فى المادة المعروضة على المتعلم فى صورة نهائية مكتملة الى حد ماهويقتصر دور التلميذ على تلقى واستقبال المعلومات و المعارف و المهارات

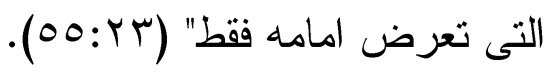

\section{القزاعات النظرية و الار اسات المرجعية القراعات النظرية: - (اع)

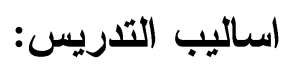

يشير عبد الحميد شرف 99 ام إلي أن التربية الرياضية تعتبر مظهراً من مظاهر الثربية

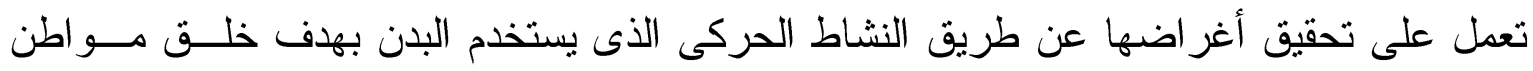

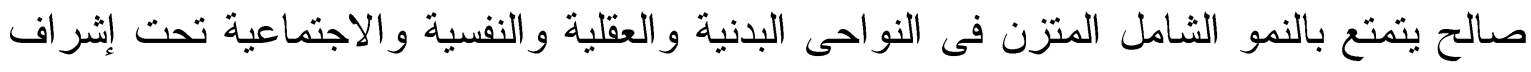

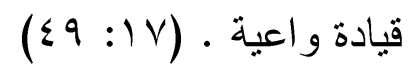

لذا كان من الضروري أن تتعدد وتتطور أساليب التدريس فى المجال الرياضى لنستطيع

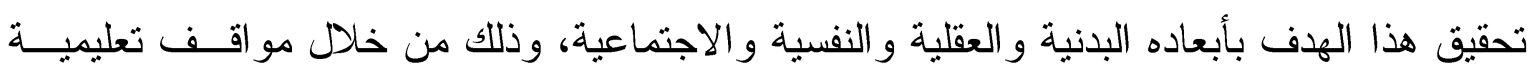

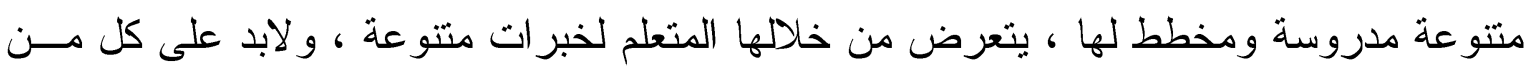

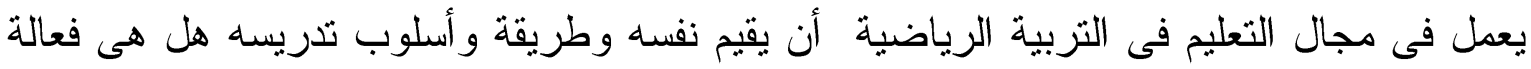

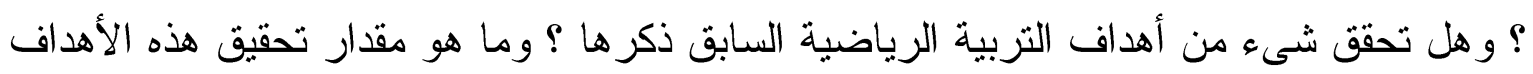




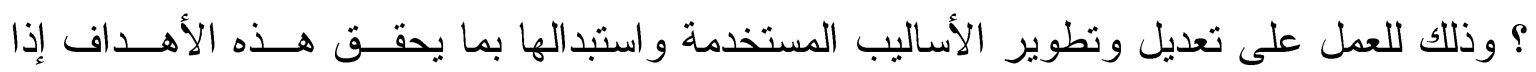

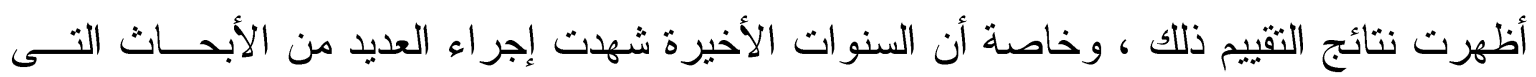

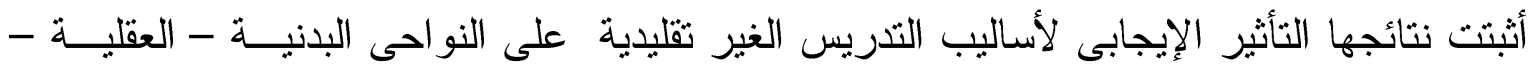

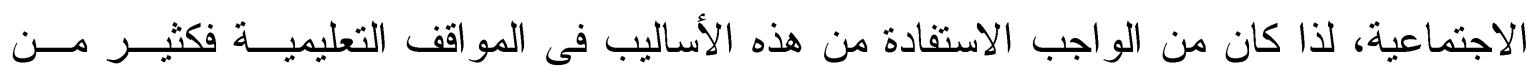

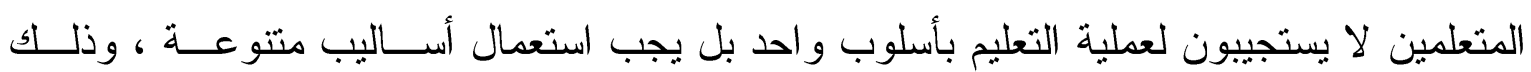
لمر اعاة الفروق الفردية بين المتعلمين.

و يرى سعيد خليل الثـاهل ه99 ام أن مفهوم الأسلوب فى مجال التدريس يعنـى شـــلا

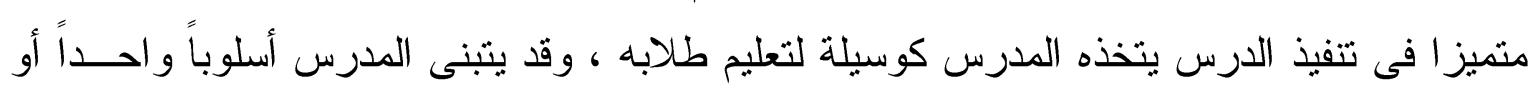

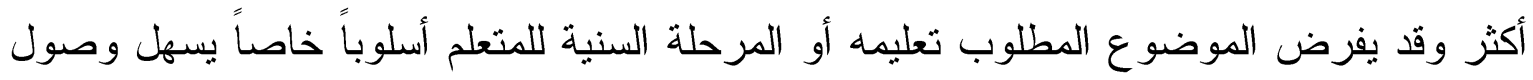

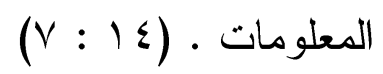

وتذكر كل من نوال إبراهيم شلتوت ، ميرفت علي خفاجة ب ـ . ب م أن أســلوب التـدريس

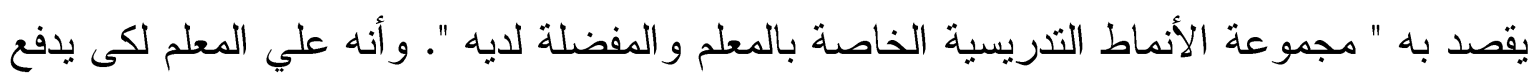

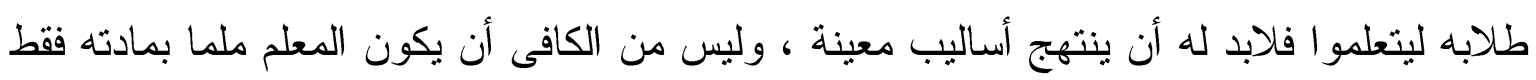

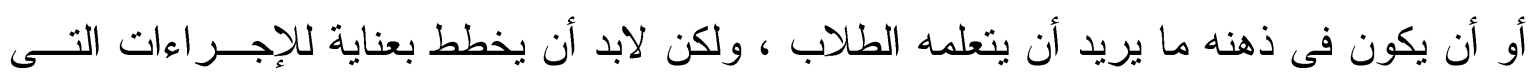

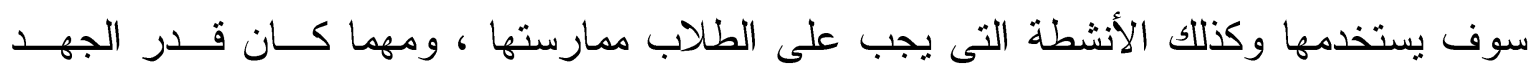

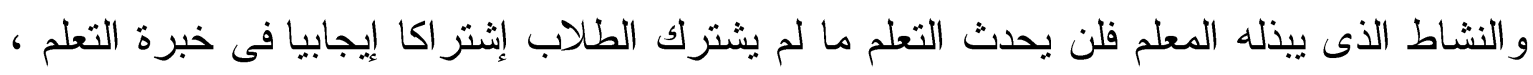

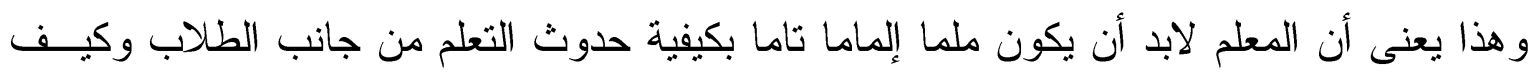

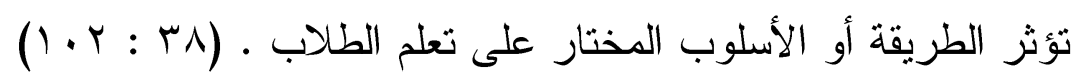

اسلوب الاوامر The command style:

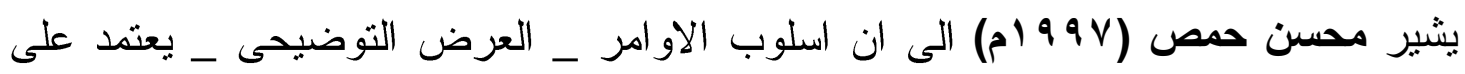

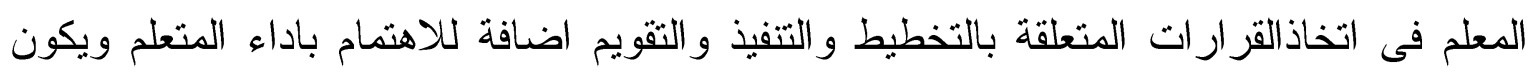

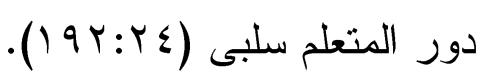

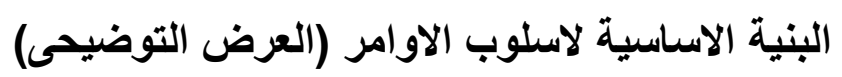

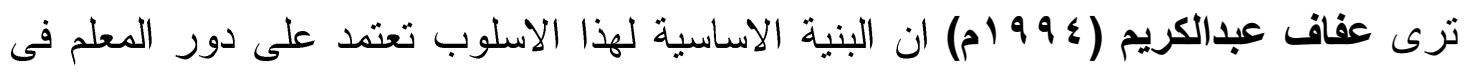

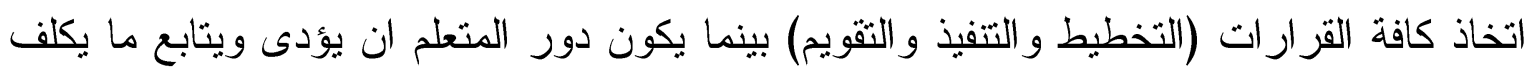
به. و هواسلوب مباشر بين المعلم والمتعلم يظهر من خلال استجابات المتعلم لتعليمات المعلم

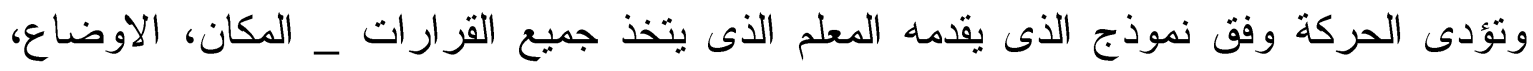

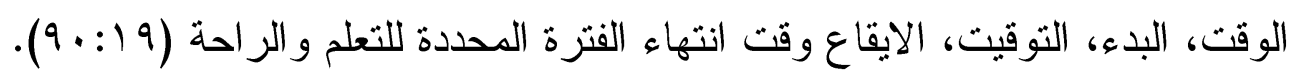


مضمون اسلوب الاوامر - الموضو ع الدراسى ثابت ويمتل مستوى و احد.

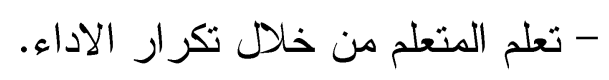

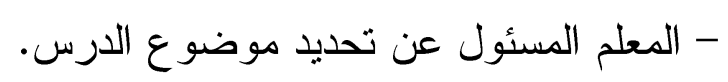

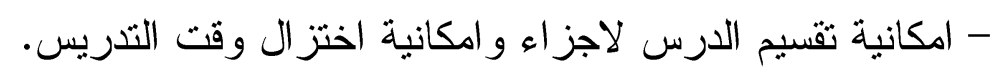

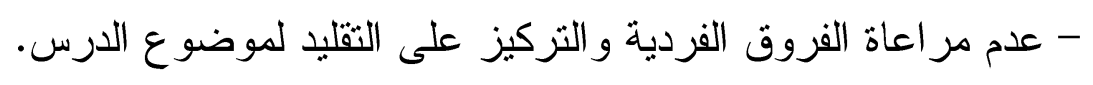
- من خلال التكر ار يمكن ان يتوحد اداء المتعلمين. - عدم السماح للمتعلم بالمناقشة و الحوار .

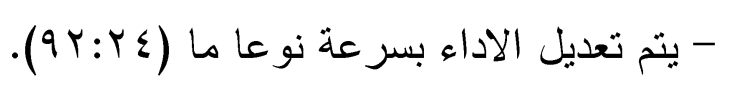

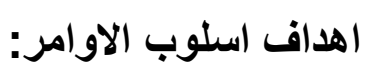
- الاستجابة المباشرة.

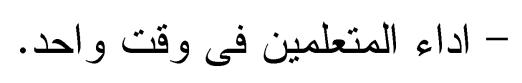

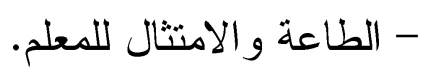

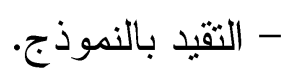

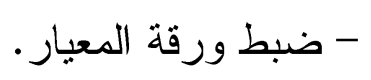

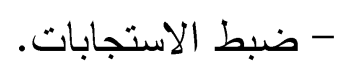
- اصلاح المعلم لاخطاء المتعلمين وفقا للهدف المهارى المحدد (9 (: 9.9، (9).

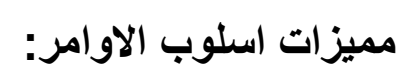
يرى سعيد الثاهد (99V (9) انه رغم دكتانورية اسلوب الاوامر الا انه يتمتع ببعض المزايا

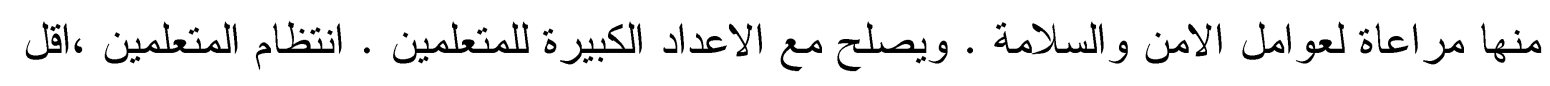

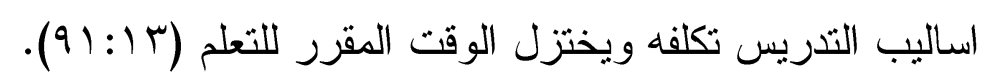
عيوب اسلوب الاوامر:

يشير سعيد الثاهد (99V (م) الى ان لاسلوب الاوامر عيوب وهى عدم مراعاة للفروق

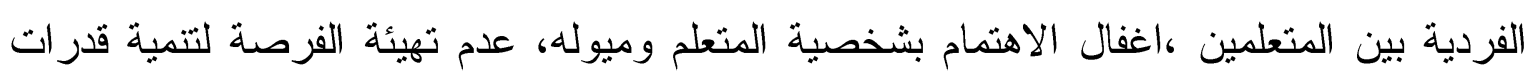
المتعلمين، النمو الانفعالى و الاجتماعى لبعض المتعلمين فقط، الناكيد على السلبية للمتعلمين و النشاط

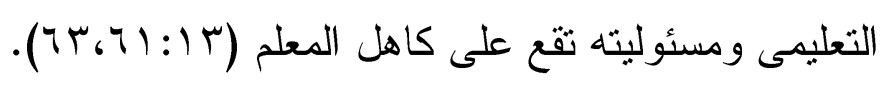

\section{اسلوب الاكتثاف الموجه Guided Dis covery:}

اسلوب الاكتشاف الموجه احد اساليب التدريس الذى هو عبارة عن تعلم استقصائى بحثى ذاتى

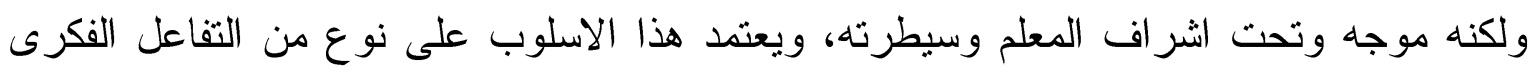


بين الدرس و الطلاب، اذ يقوم بطرح اسئلة متتالية عليهم يقابلها استجابة حركية منهم ، اى سؤال

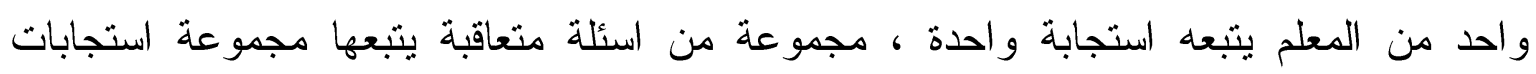

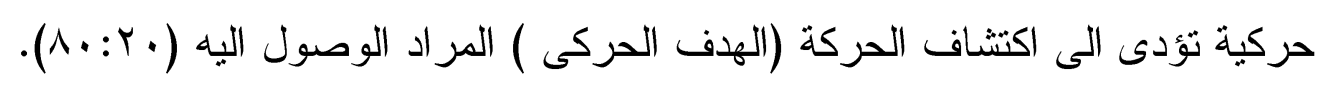

وتثير عفاف عبدالكريم (ع 99 (1) الى ان المعلم فى هذا الاسلوب مسئو لا عن اجراءت

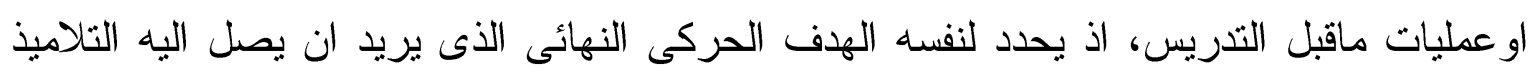

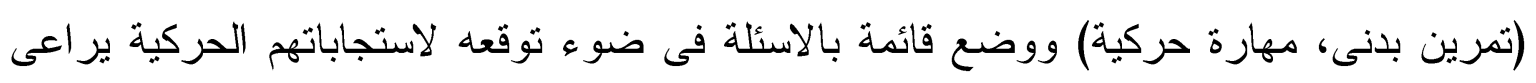

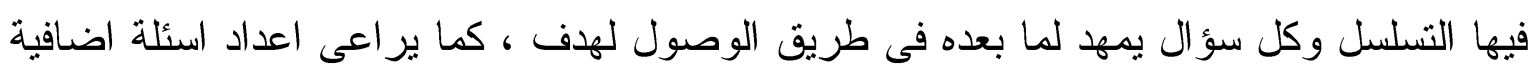

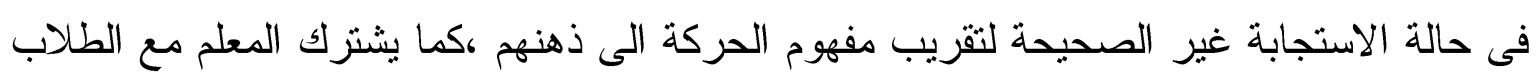

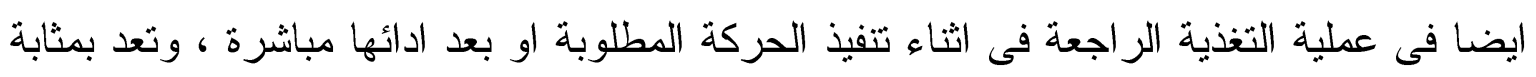

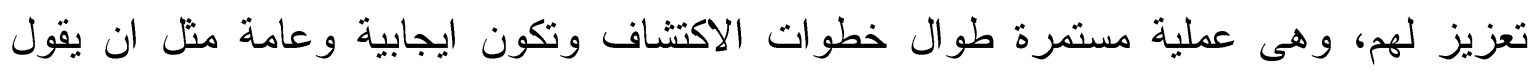

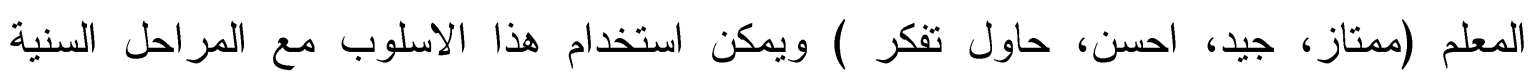

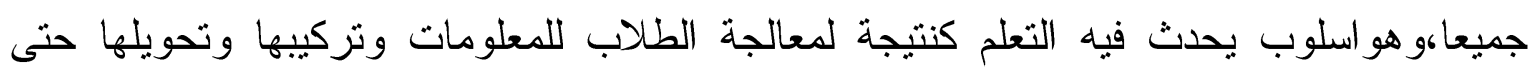
يصل الى معلومات جديدة .أما اسلوب العرض التوضيحى فهو من اساليب التدريس المباشرة،

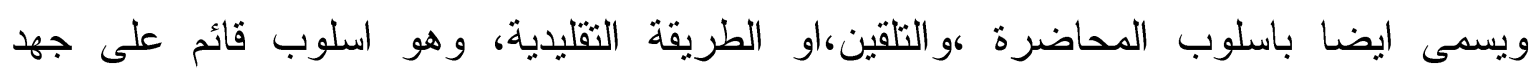

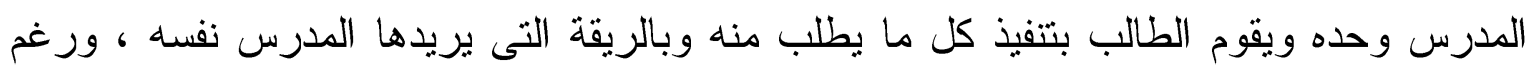
هذا يمكن من خلاله توجيه الثرح للطلاب كلهم لمعرفة الخطوات الاولية لتتفيذ المهارة الحركية

ان مهمة المعلم التوجيه نحو الاكتثاف الموجه ويكون مرشدا للتلاميذ بشجعه على البحث

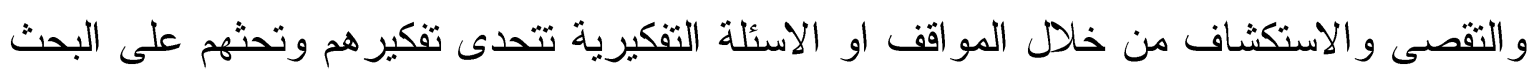
و الملاحظة و القياس و التتبؤ اما المتعلم فهو نشط فى العملية التعليمية ويتحمل جانبا من مسئولية

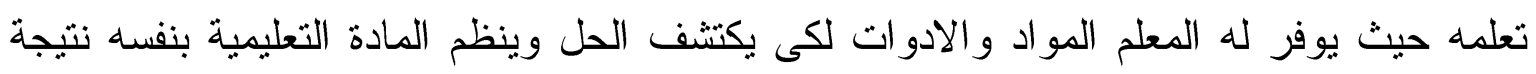

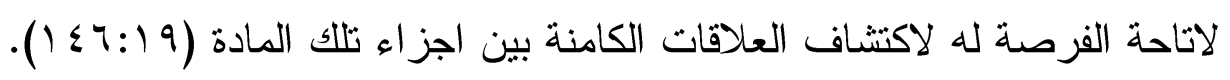

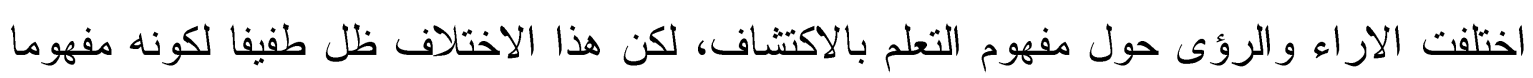

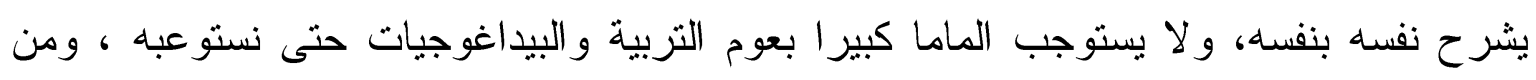
هذه التعاريف نذكر: ا- التعلم بالاكتشاف استراتيجية وعملية تفكيرتتطلب من الفرد تتظيم معلوماته وتكيفهها بشكل يمكنه من رؤية علاقات جديدة لم تكن معروفة لديه من قبل. 
ץ- تعلم يحدث كنتيجة لمعالجة المتعلم للمعلومات وتركيبها وتحويلها، حتى يصل الى معلومات جديدة باستخدام عمليات الاستقر اء او الاستنباط او ائه طريقة اخرى.

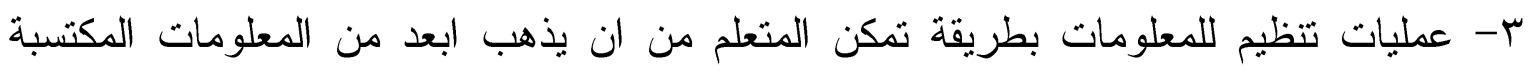
سابقا. ع- محاولة الفرد الحصول على المعرفة بنفسه دون مساعدة من المدرس عبر استعمال معلومات سابقة للوصول الى معلومات جديدة.

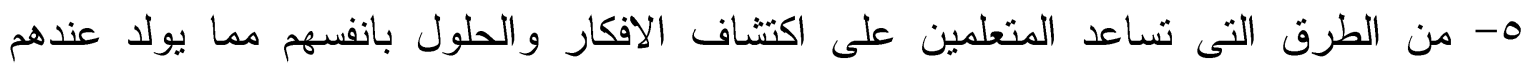
شعور ا بالرضى و الرغبة فى مو اصلة التعلم.

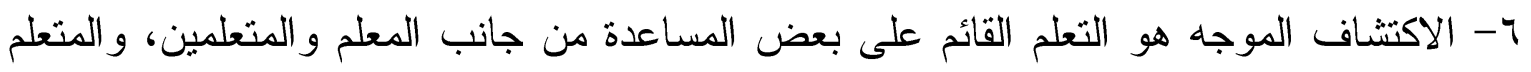
هو الذى يقوم بالدور الرئيسى فى عملية التعلم اما دور المعلم فيقتصر على توفئ توجيه الدتعلم وتحفيزه

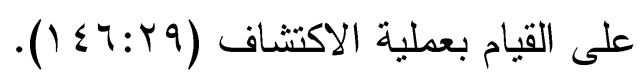
مضمون الاسلوب: 1- يكون المعلم مسئولا عن عمليات التدريس حيث يحدد المتعلم الهدف الحركى النهائى المراد الوصول اليه (تمرين بدنى - مهارة حركية). ץ- يعد المعلم قائم بالاسئلة فى ضوء توقئ لهعه لاستجابات الطلبة الحركية ير اعى فيها التسلسل وكل

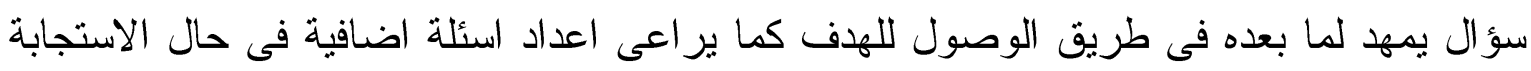
الغير صحيحة للطالب لتقريب مفهوم الحركة الى ذهنه. ب- يشترك المعلم مع الطالب فى عملية التتفيذ حيث يلقى الاسئلة ثم يودى المتعلم الحركة للاجابة على هذه الاسئلة من خلال تتشيط الحركة الفكرية.

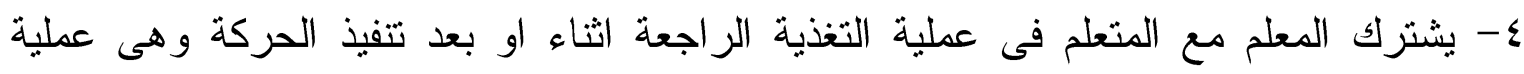
مستمرة طو ال خطوات الاكتثاف وتكون ايجابية وعامة مثل ان يقول المدرس (ممتاز - جيد صح - لا بأس - حاول تفكر بطريقة اخرى).

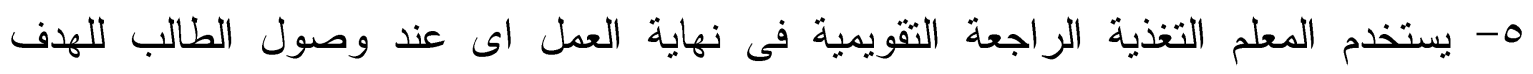

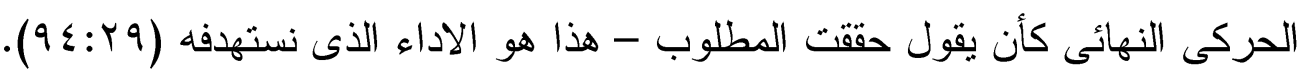
اهداف اسلوب الاكتثاف الموجه: 1 - اشغال المتعلم بفكرة معينة تشغل تفكيره باستمر ارهن r- ايجاد علاقة بين الحافز والاستجابة. r- دفع المتعلم الى اكتشاف اشياء متتالية توصله الى اكتئه التشاف مفاهيم دعينة.

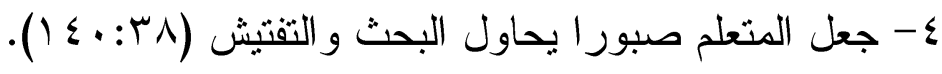




$$
\begin{aligned}
& \text { مميزات اسلوب الاكتثاف الموجه: } \\
& \text { 1- التغذية الر اجعة مستمرة. }
\end{aligned}
$$

ץ- ينمى لدى الطالب الاستقلالية و الاعتماد على النفس. r- يقلل من ظاهرة النسيان ويجعل المادة قابلة للفهم و الاستيعاب.

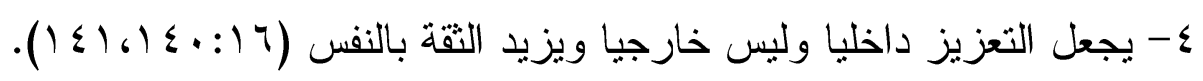
انواع التعلم بالاكتشاف:

تم تقسيم الاكتثاف الى ثلاثة انو اع (اكتشاف موجه، اكتثاف شبه موجه، اكتثاف حر).

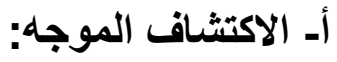

من خلال مصادر المعلومات المطلوب منهم اكتشافها، وهذا الاسلوب مناسب لمتعلمى الاكي المر احل التعليمية الاولى (الابندائية) حيث يمثل اسلوبا تعليميا يسمح لهم بتطوير معرفتهم من خلاد

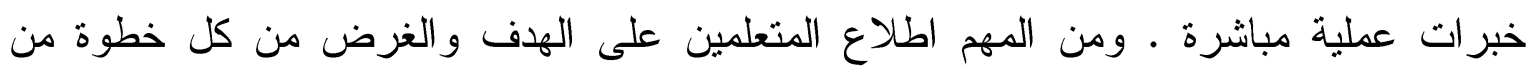

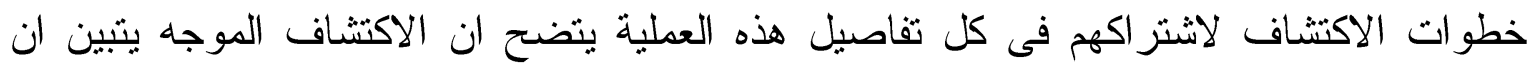

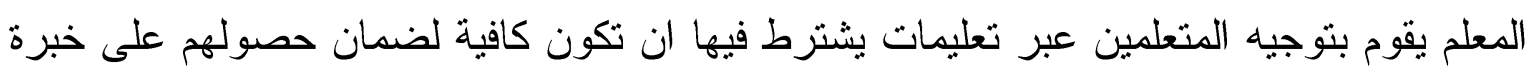

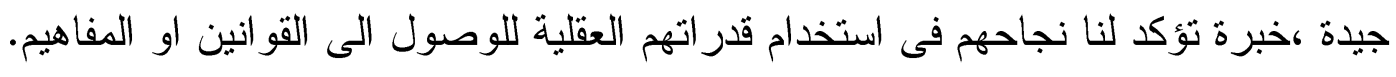
ب- الاكتثاف شبه الموجه:

يكتفى فيه المعلم بعرض الثكل وتقديم مرفقا باقل قدر مدكن التوجيهات و التعليمات ،لاعطاء

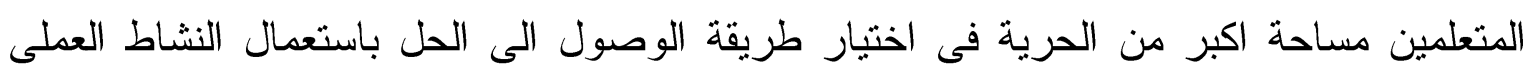
و العقلى،كل حسب وتيرته وطريقة عمله (الفروق الفردية).

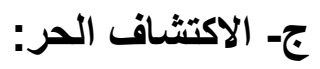

الاكتشاف الحر او المتقدم بتعبير ، يواجه فيه المتعلمون مشكلة معينة ثم تترك لهم حرية

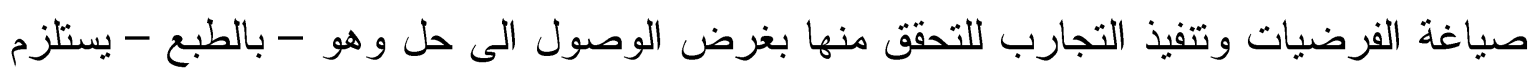

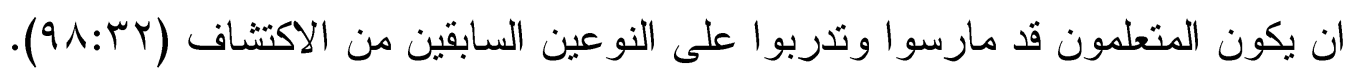

\section{دور المعلم فى التعلم بالاكتثاف الموجه:}

1 - تحديد المفاهيم العملية و المبادىء التى سيتم تعلمها وطرحها في صورة التهام تساؤل او مشكلة. r- اعداد المواد التعليمية اللازمة لتنفيذ الدرس.

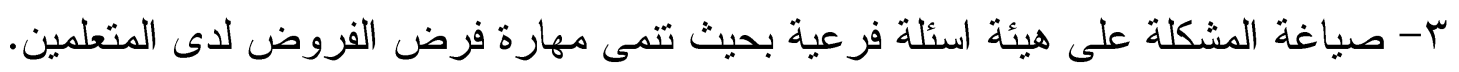
ع - تحديد الانشطة او التجارب الاكتثافية التى سينفذها المتعلمون.

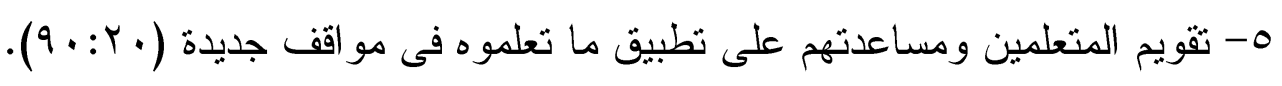


وترى نوال شلتوت، ومحسن حمص (^^. . rم) ان مراحل التدريس فى اسلوب الاكتثاف

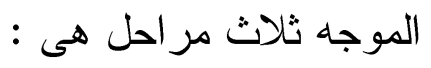

$$
\begin{aligned}
& \text { - مرحلة ما قبل الدرس (للمعلم). } \\
& \text { - مرحلة اثثاء الدرس (للمتعلم - المعلم). }
\end{aligned}
$$

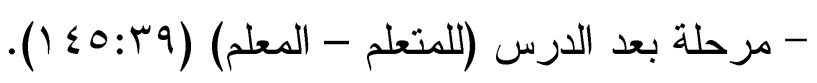

$$
\begin{aligned}
& \text { اسلوب التدريس (توجيه الاقران): } \\
& \text { هو عبارة عن انشطة تعليمية تاتى على هيئة: }
\end{aligned}
$$

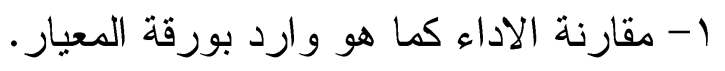

$$
\begin{aligned}
& \text { r- استتناج اذا كان الاداء صحيحا. }
\end{aligned}
$$

r- توصيل النتائج ويمكن ان تقدم التغذية الراجعة الثاء الاداء أواء بعد الانتهاء منه وقد تكون متضمنة فى الاداء نفسه مثل التصويب فى كرة السلة. ع- الاتصال بالمدرس اذا كان ذلك ضروريا.

$$
\text { 0- دور المعلم: - الانصال بالمدابن }
$$

أ- الاجابة على اسئلة الملاحظ. ب- الاتصال فقط بالملاحظ.

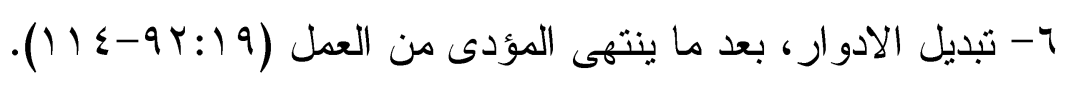

\section{مضمون اسلوب التطبيق بتوجيه الاقران:}

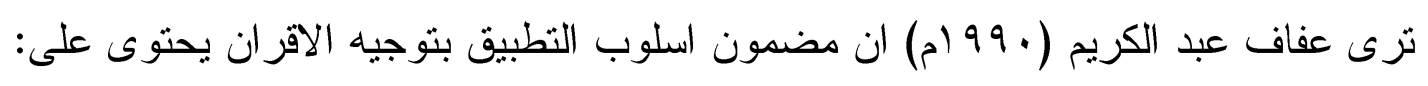
أ- يتقبل المعلم العملية الاجتماعية بين الملاحظ و المؤدى كهدف مطلوب في النى التعليم.

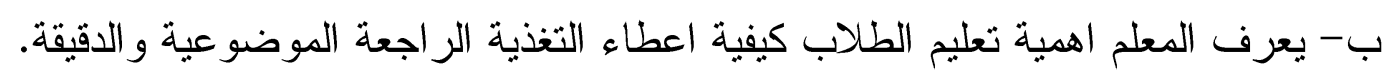

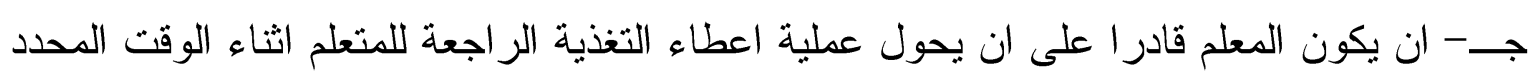
للفقرة التعليمية.

د- يمارس المعلم سلوكا جديدا يتطلب عدم الاتصال المباشر للتلميذ.

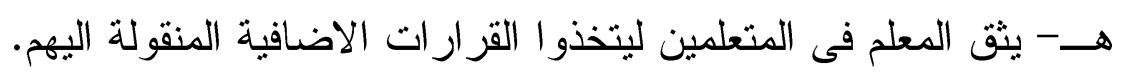

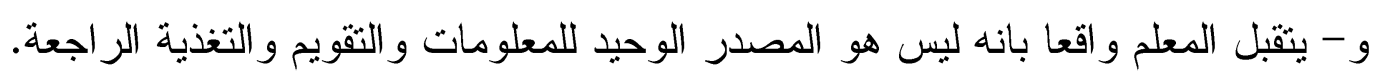

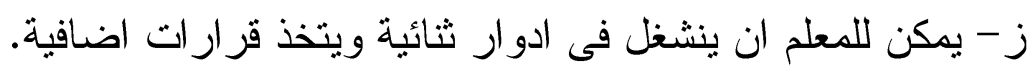

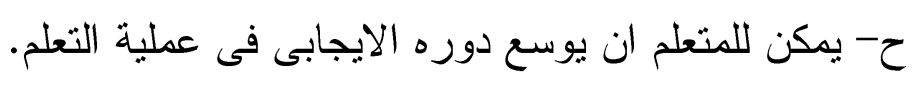
ط- يمكن للمتعلم ان يرى ويتقبل المعلم فى دور غير للادوار التى فئى يؤديها فى الاساليب الاخرى. 
ى - يمكن للمتعلم ان ينشغل فى علاقة ثائية دون تو اجد المدرس الدائم باستخدام ورقة المعيار (1) (1) $11 \leq: 4 \cdot)$

وصف البنية الاساسية لاسلوب التطبيق بتوجيه الاقران:

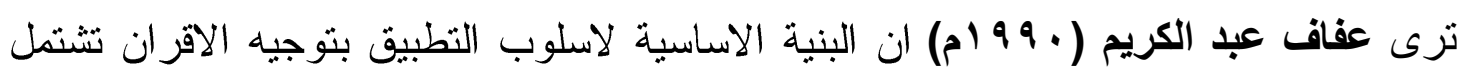
على عدو قرار ات يجب اتخاذها فى اى فقرة لفظية وتنظم بنود القرارت فى ثلاث مجمو عات هى: أ- قرارات التخطيط:

وهى مجموعة من الاجر ارات التى يتخذها المدرس،قبل تتفيذ الفقرة اللفظية.

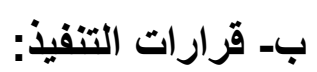

هى الاجراءات التى يتخذها المعلم وهى مجموعة القرارت التى ندت اليه من قبل المعلم

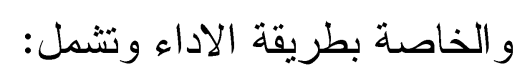
-الاوضاع: لتحقيق الهدف من العمل فما هى الاوضاع ولئه الاكثثر مناسبة. 1- المكان: كل عمل يؤدى فى مكان معين فما هو انسبها.

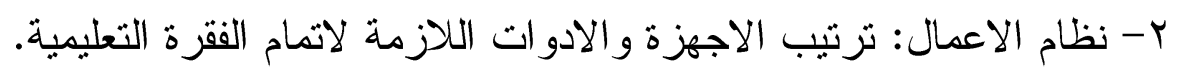

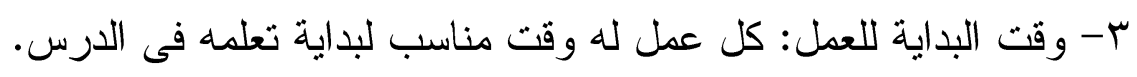
ع- التوقيت و الايقاع الحركى: لكل حركة توقيت و وايقاع حركى يناسبها. ه- الانتهاء من العمل: اتخاذ القرار عن انتهاء الفقرة التعليمية.

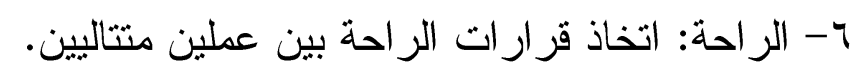
V- المظهر: يشير الى مظهر المتعلمين فى صالة اللعب او الملعب.

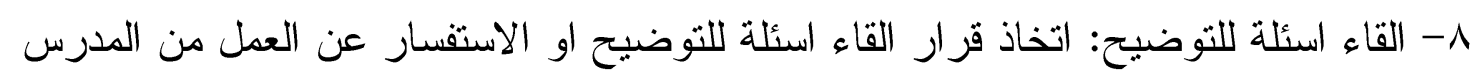
(l) (1):r.)

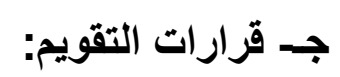

يشير على الديرى (T/91/م) الى انه غى بنية الاسلوب يكون دور المعلم هو اتخاذ جميع

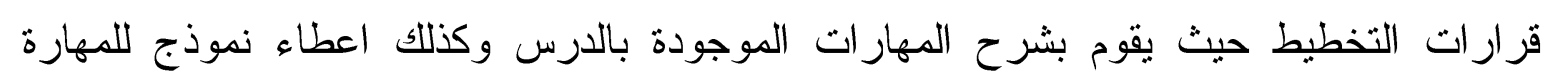

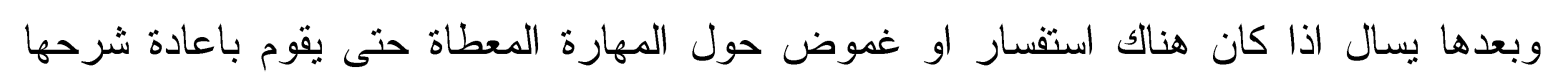

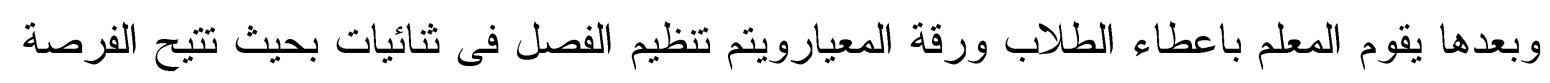
لتقديم التغذية الراجعة مباشرة ويكلف كل فرد بدور خاص بحيث يقوم احدهم بالاداء والاخر

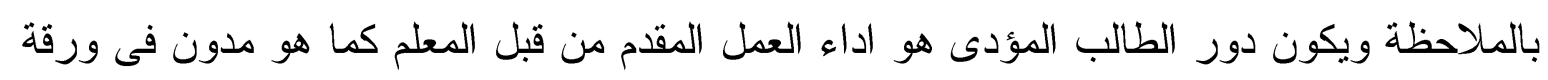

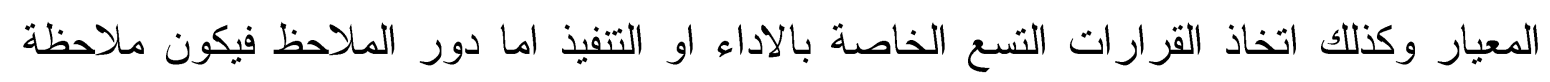


المؤدى و اعطاء تغذية راجعة خاصة بالاداء وتصحيح الاخطاء ويكون دور المعلم ملاحظة كل من

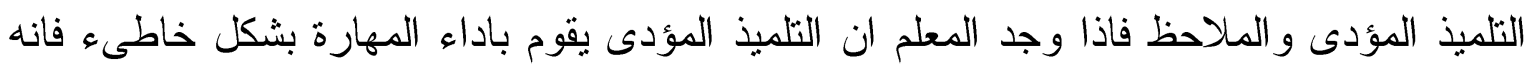

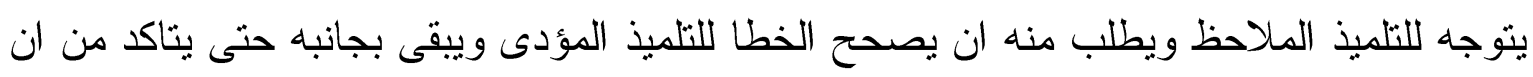

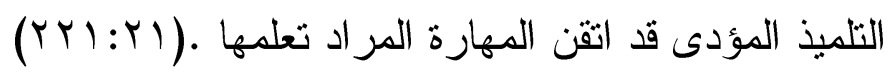
الاهداف التى يحققها اسلوب التطبيق بتوجيه الاقران:

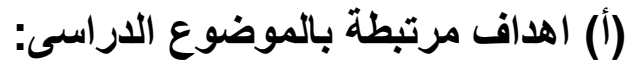

- اتاحة الفرصة المتكررة لممارسة العمل مع شخص بالمص ملاحظ. - ممارسة العمل تحت ظروف الحصول المباشر على التغذية الر اجعة من الزميل. - ممارسة العمل دون ان يقدم المدرس التغذية الراجعة او معرفة متى تصحح الاخطاء. - اتاحة قدرة التلميذ على مناقشة جو انب معينة من العمل مع الزميل. - تصور وفهم الاجزاء وتعاقبها فى اداء العمل. (ب) اهداف مرتبطة بدور المتعلم:

- الانشغال فى عملية اجتماعية تناسب الاسلوب و اعطاء و استقبال تغذية راجعة من الزميل.

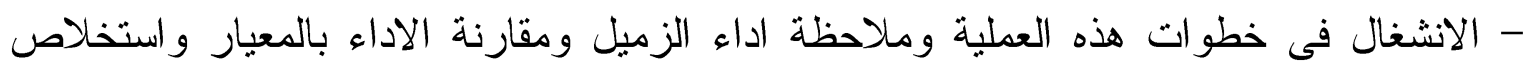
استتاجات وتوصيل النتائج للزميل. - ممارسة التخذية الر اجعة المتاحة فيتعلم كيف يعطى التخدية الترائ التعة الصحيحة.

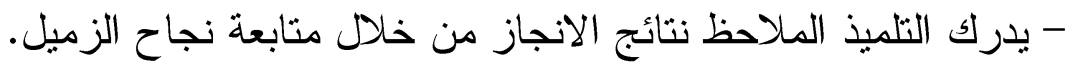

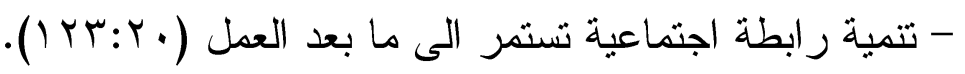

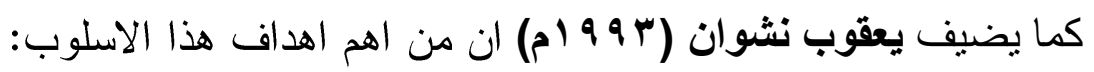

أ- تلبية حاجات المتعلمين فى حرية اتخاذ القرارت وحب الاعتماد على النفس و العمل المستقل.

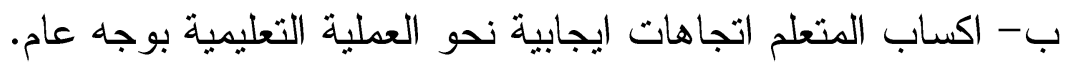
جـ- تطوير التفاعل بين المعلم و المتعلم (احتر ام شخصية المتعلم). د- تتمية المهار ات العملية نتيجة الممارسات الذاتية للانشطة من قبل المتعلم.

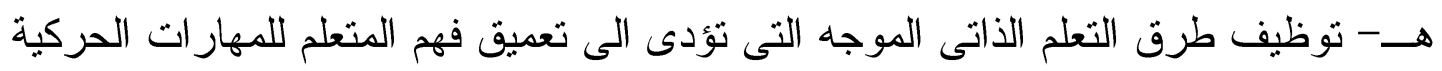
. (00,0 $0: 17)$

مميزات اسلوب التطبيق بتوجيه الاقران:

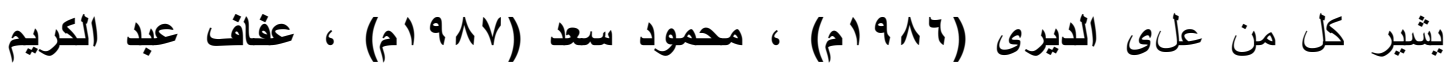

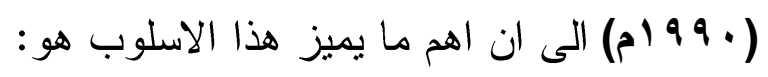
أ- توفير زمن كاف للنطبيق. 
ب- تحويل قرارات معينة من المعلم الى المتعلم ، توجد علاقات جديدة بين المعلم والمتعلم وبين المتعلم و الاعمال التى يؤديها وبين المتعلمين انفسهر.

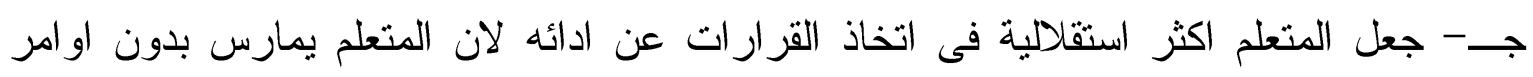
المدرس. د- يفيد فى المرحلة الاولى من تعلم المهارة عندما يحتاج الطلاب الى التعرف على نقاط تعليمية هامة بعد كل محاولة لتساعدهم على تصحيح ادائهم. هـ- يعتبر هذا الاسلوب بمثابة توفير مدرس لكل طالب. و - يساهم فى تتمية السلوك التعاونى. دون. ز - تحقيق مجموعة مختلفة من الاهداف، منها ما له صلة بالاداء واخرى لهاء له صلة بالفرد من حيث

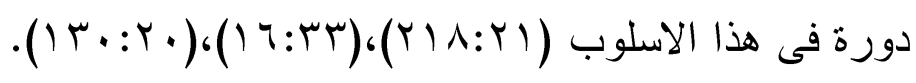
وسيلة عرض البرنامج فى اسلوب التطبيق بتوجيه الاقران:

ورقة المعيارCriterion Sheet:

وتثير عفاف عبدالكريم (ع 99 ام) الى ان العامل الوحيد الذى يقرر النجاح او الفشل فى هذا

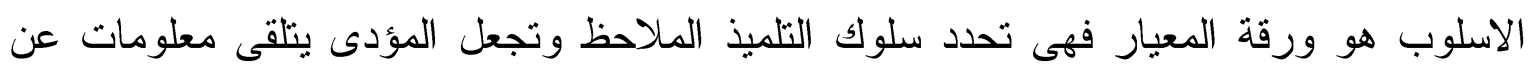

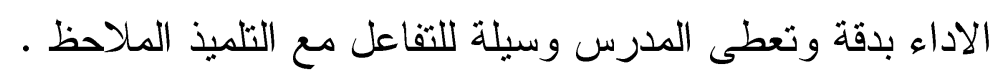

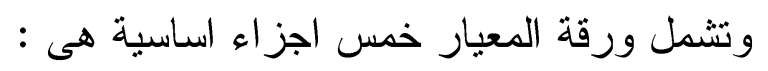
1- وصف خاص للعمل ويشمل تقسيم العمل الى اجز اء متتابعة. r- نقاط تعليمية تلاحظ اثناء الاداء. r- ب- رسومات او صور للعمل. ع- عينة من السلوك اللفظى الذى سوف بستخدم وهى تقبد عند تتفيذ الخبات الاولى لهذا الاسلوب.

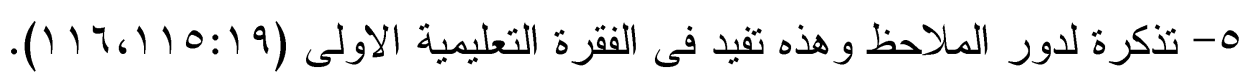

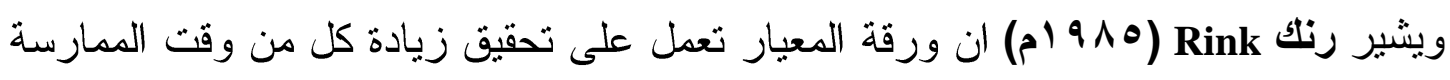

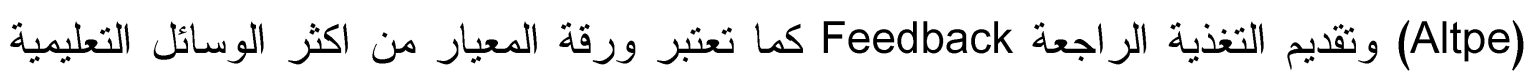

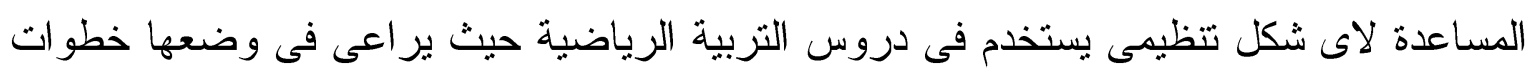
اعداد البرنامج ان تحقق الاهداف التالية: 1- تحديد الاهداف العامة من تعلم المهارة ومساعدة الطالب على تذكر المهارة التى سوف يؤديها وكيفية ادائها حتى تصبح بمثابة المعايير السلوكية Criterion behavior لمستويات الاداء

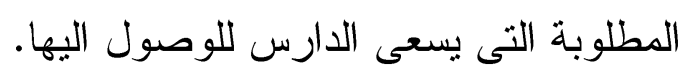


ץ- تحليل كل سلوك تعليمى وتحديد المهام التعليمية التى يؤدى الاستجابة اليها الى اكتساب السلوك

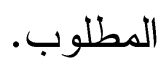

ז- مقارنة الاستجابة بالمعيار الخاص بالمهارة لكى تساعد المتعلم على تحسين و اتقان الاداء.

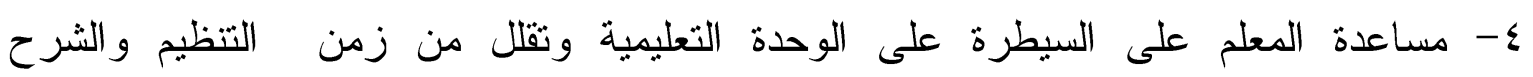
$\cdot(1 \leqslant \cdot: \leqslant Y)$

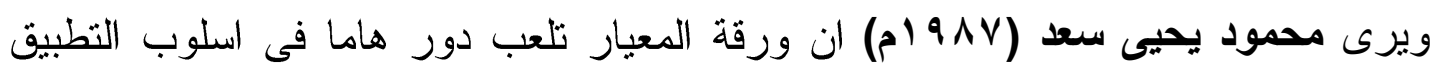
بتوجيه الاقران خلال مرحلة التنفيذ لكى تزيد من فاعلية الزمن الفعلى للممارسة العلمية للمهارة

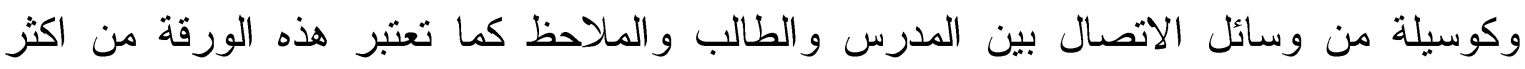
الوسائل التعليمية المساعدة فى تعلم المهارات وذللك بتحقيقها الاهداف التالية: 1- مساعدة الطالب على تذكر المهارة التى سوف يؤديها وكيفية ادائها. ץ- تركيز الطلاب على شرح المدرس لكل مهارة من البداية حتى نهاية الاداء.

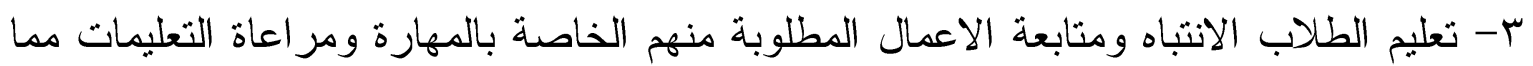
يساعد على تحسين و اتقان المهارة. ع- التقليل من زمن شرح المدرس للمهارة. 0- مساعدة المدرس على الالمام بالوحدة التعليمية (المهارة) ويجب ان يرحة اعى فى تصميم ورقة

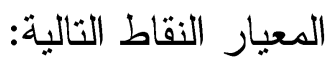
أ- توضيح المهارة جزئيا فى صور مسلسلة مصحوبة بالنقاط الفنية الهامة. ب- توضيح كيفية اداء المهارة طبقا للنسلسل و التندرج

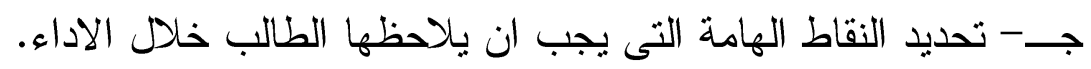

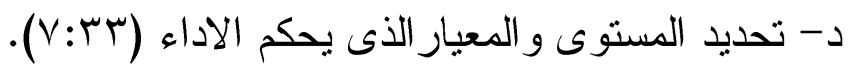
خطوات تصميم ورقة المعيار: أ- تشمل ورقة المعيار المعلومات (الاخطار ات) الضرورية عما يفعل وكيف يعمل المتعلم. ب- وصف محددات العمل. جـ- تحديد عدد التكر ار، المسافة ،الزمن(الكم). د- استخدام شكلين من اشكال السلوك اللفظى مثل: - عملك هو تادية ثلاث تصويبات من الثبات (وهى صيغة المصدر). 
- صوب ثلاث تصويبات من الثبات (وهى صيغة الامر). هـ- تخصيص مكان للملاحظات، خاصة بتقدم المتعلم، ملاحظات التغذية الراجعة، معلومات اخرى. و - اشتمال الورقة على بيانات- التاريخ- الفصل، الاسم، اسم الزميل، ورقة المحاضرة، الاسبوع. ز - ترقيم الورقة ( ) ) وذذا يساعد على حفظها منظمة ومعدة للاستخدام فى اى وقت. ح- الموضوع العام: ويشير الى اسم النشاط او الرياضة المنداولة (العاب قوى). ط- الموضوع الخاص: يشير الى مهارة معينة فى النشاط مثل (الوثب الطويل). ى- وصف العمل: ويرصد بالخانة الخاصة بذلك لوصف الاعمل وعناصر ها ويصاحب الوصف توضيحات للعمل واجز ائه و التوضيح يكون رسما او صور للاوضاع المطلوبة. ك- توجيهات للمتعلم: وصف الغرض من النشاط او اى معلومات قد يحتاجها المتعلم. ل - يدون الكم لكل عمل (عدد التكرار - زمن الاداء).

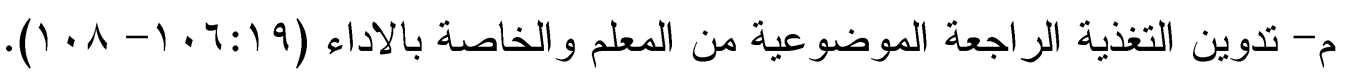

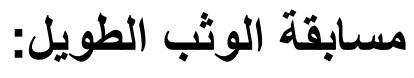

تعتبر مسابقة الوثب الطويل من أقدم المسابقات في ألعاب القوى فقد كان أول من مارسها

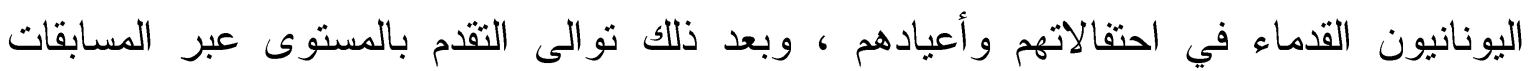

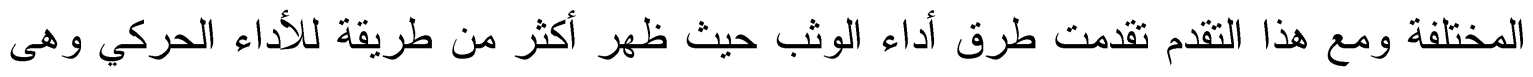
(الوثب بطريقة التعلق - الوثب بطريقة المشي في الهواء) ، وتعتبر مسابقة الوثب الطويل عبارة

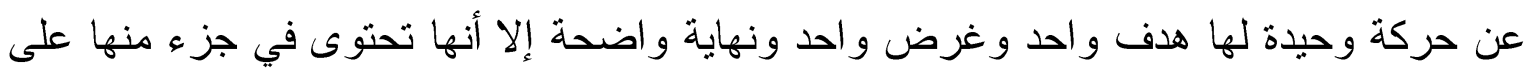

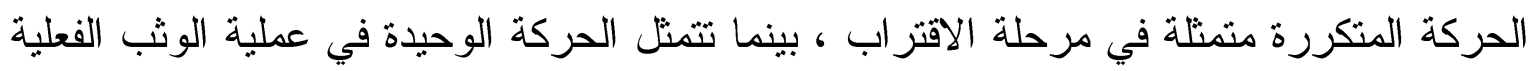

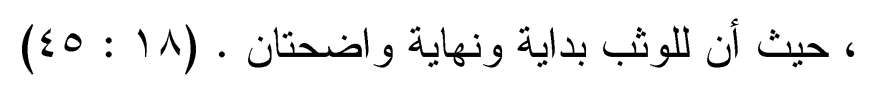

ولقد اتفقت أغلب المراجع و الدراسات على أن تكنيك الوثب الطويل يحتوى على أربع مر احل فنية أساسية هي (مرحلة الاقتراب - مرحلة الارتقاء - مرحلة الطير انكان - مرحلة الهبوط). مرحلة الاقتراب .

إن الهذف الرئيسي هو الحصول على سرعة عالية بالإضافة إلى تحضير جيد للارتقاء ، ويراعى الإلى

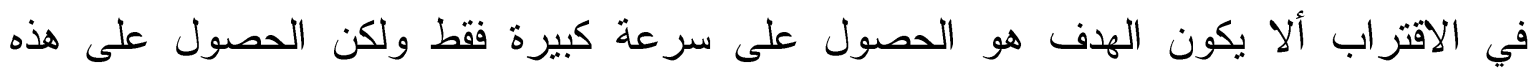


السرعة يجب أن يستمر خلال الخطوات الاخيرة قبل الارتقاء وينقسم الاقتراب إلى مرحلتين مهنتين هما (مرحلة التدرج في السرعة - مرحلة التحضير للازتقاء) . مرحلة التدرج في السرعة : ماري

ويبدأ المنسابق عادة الخطوات الاولى بقوة ولكن دون أي تقلصات ،حيث يلاحظ أن يلازم

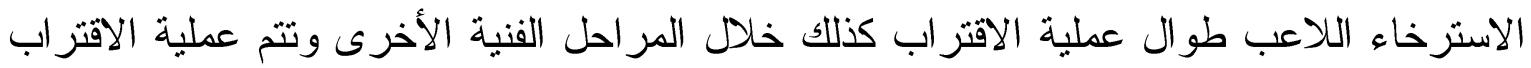

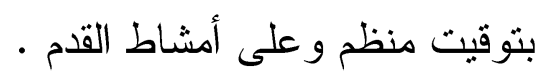

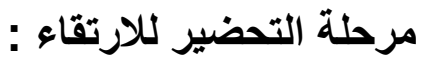

في هذه المرحلة يتم عمل تغيير طفيف في هيكل الخطوات المستخدمة بهدف تأمين الثروط الميكانيكية للارتقاء من هنا كان لابد من العمل على خفض مركز تقل الجسم والجدير بالذكر هنا

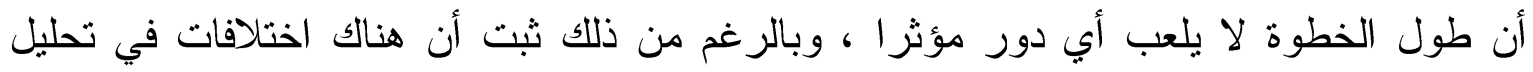

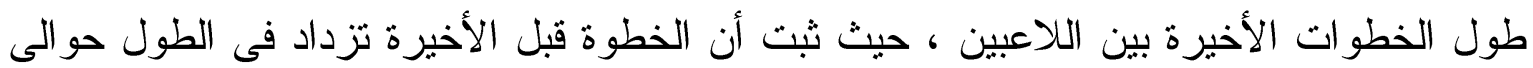
. . سم عن الخطوة التي تسبقها والخطوة التي تليها ، ومن خلال هذا التغير يتم خفض مركز تقل

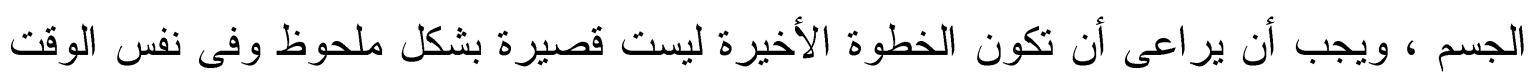

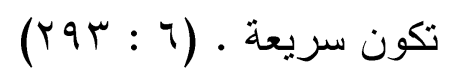

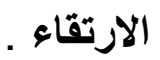

تعتبر مرحلة الارتقاء أهم مرحلة من مراحل الأداء الحركي كما أنها تعتبر عملية معقدة حيث

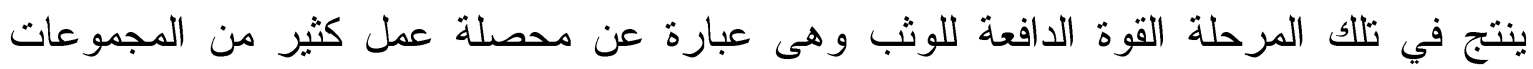

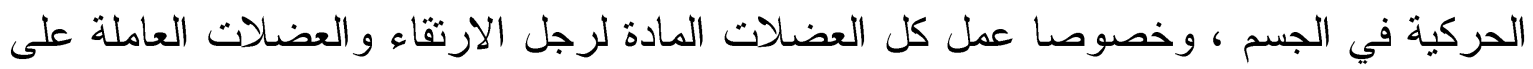
مرجحة الرجل الحرة والذراعين أثناء الارتقاء ، حيث تساوى تلك القوة رد فعل الارض وتتقسم

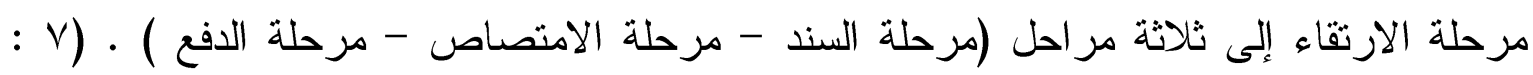

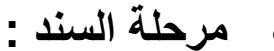

وتبدأ هذه المرحلة بوضع قدم الارتقاء على لوحة الارتقاء ويكون وضع القدم بالكعب أولا ثم بعد

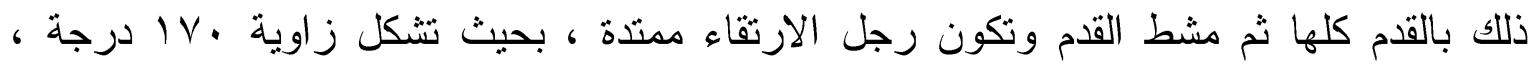

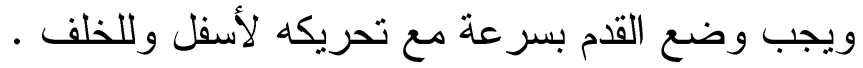




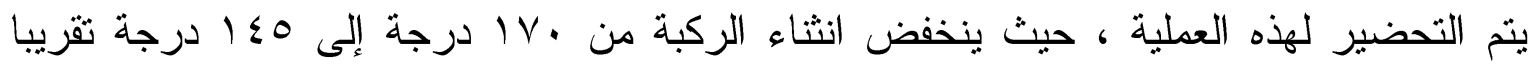

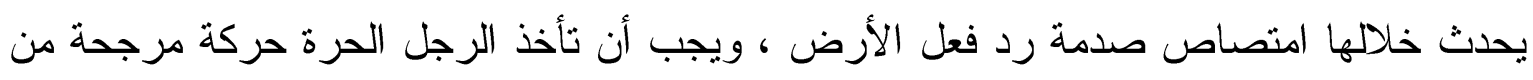

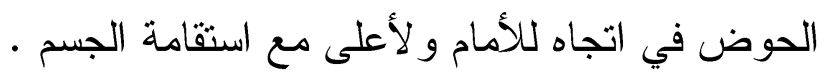

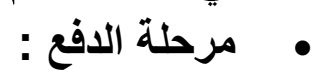

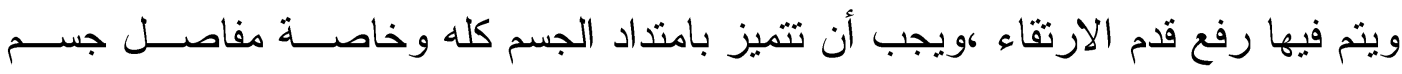

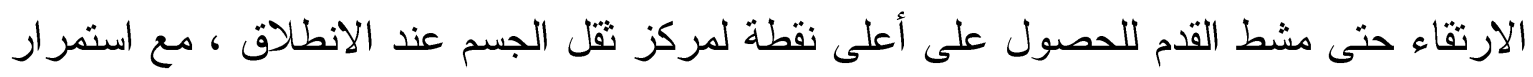

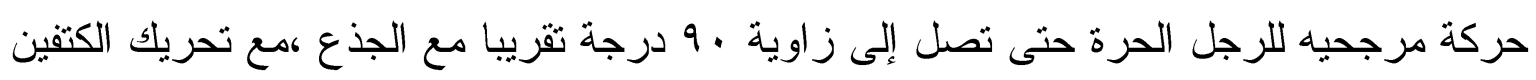

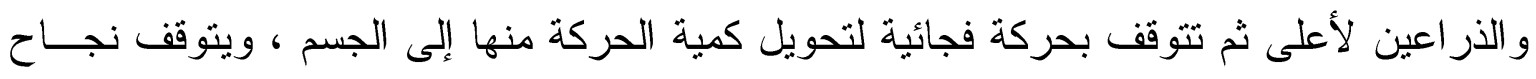

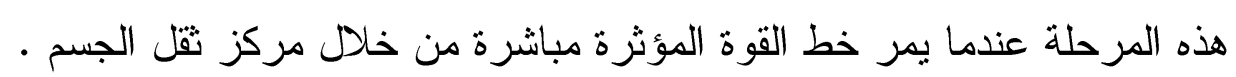
$(r 91-r 90: \curlyvee)$

مرحلة الطيران .

يمر تكنيك الطيران في الوثب الطويل من خلال عدة طرق فنية مختلفة هي :

\section{• طريقة الخطوة في الهواء :}

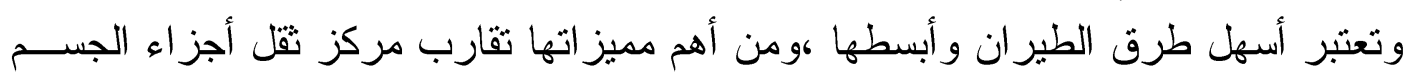

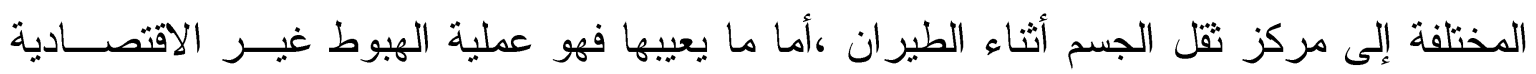

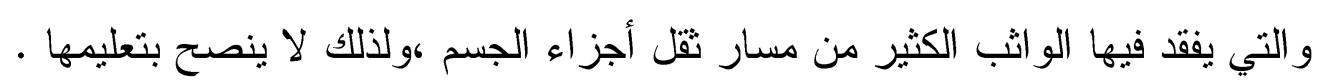

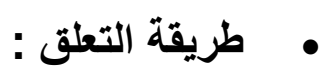

تعتبر طريقة قديمة وغير اقتصادية حيث تتباعد مر اكز ثقل أجزاء الجسم أثثــــاء الطيــران

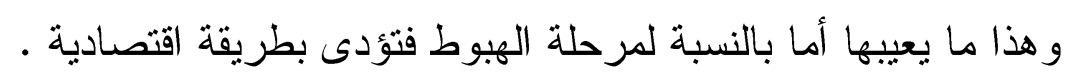

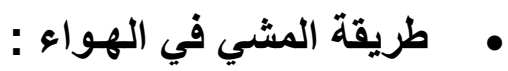

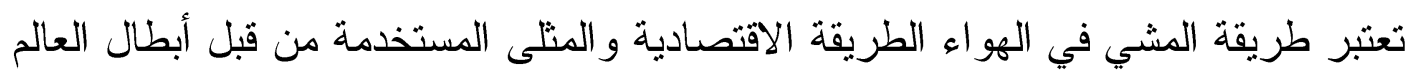

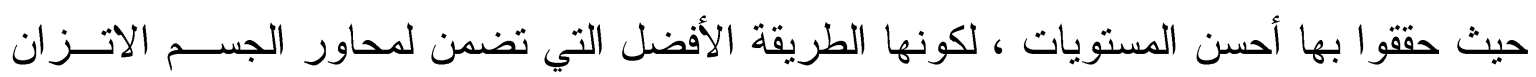

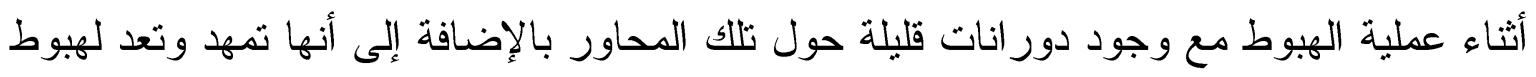

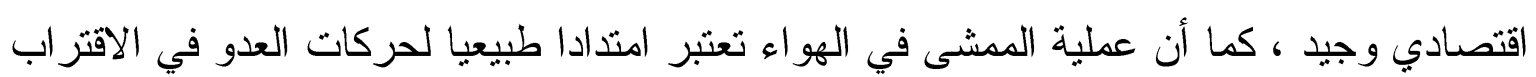

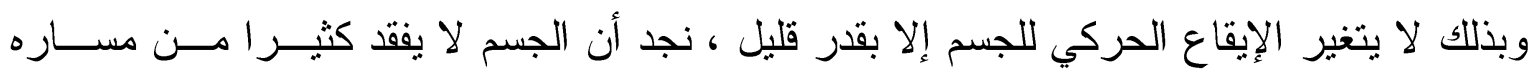

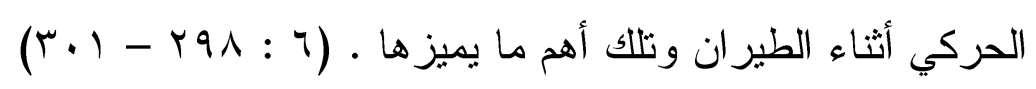


الهدف من الهبوط هو الوصول بالقدمين لأبعد مسافة ممكنة وذللك عن طريق مد الــرجلين

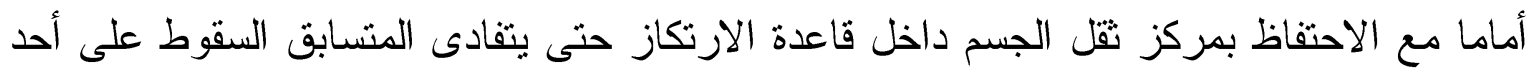

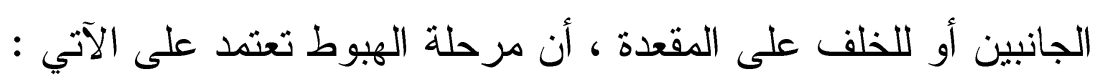

*" وضع الجسم عند إعادة الاتصال بالأرض وتتأثر بثلاث عوامل هي :

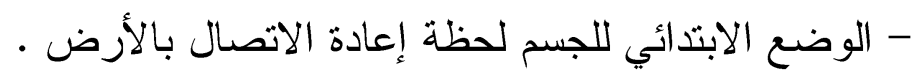

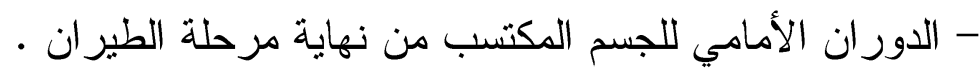

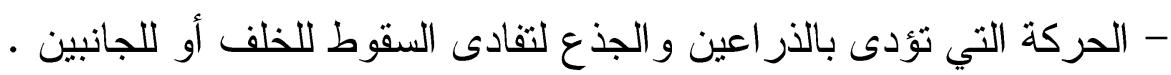

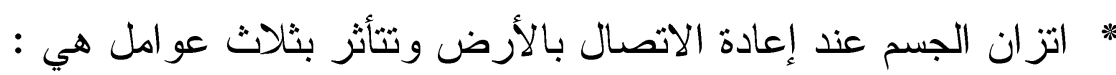

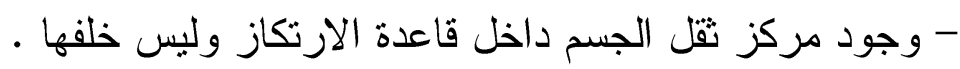

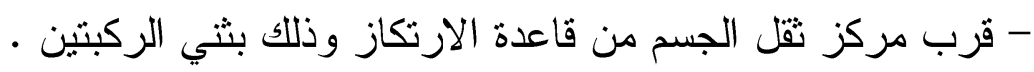

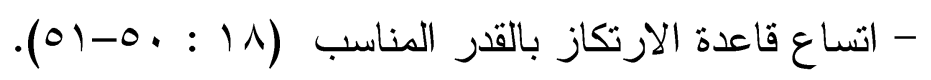

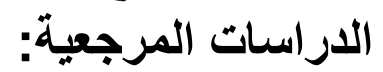

فى حدود الدراسة الحالية قام الباحث بعمل مسح للاراسات المرجعية لموضوع الدراسة فى الكثير من المصادر و المتمثلة فى رسائل الماجستير والدكتوراه و الدجلات العلمية والدوريات و المؤتمر ات العلمية بالاضافة الى الثبكة العنكبونية الدولية(الانترنت) ، وقد نم تتاول تلك الدراسات من حيث:(العنوان - الهدف - المنهج - العينة - ادوات جمع البيانات - اهم النتائج ) ، الامر الذى يتيح الفرصة لتصميم الدراسة على نحو افضل ، وهكذا تم تزتيب وعرض الدراسات ترتيبا تصاعديا من حيث تاريخ اجراء الدراسة ، وقد تم تقسيم الدراسات المرجعية الى نوعين (الدراسات العربية - الدر اسات الانجيليزية). 


\section{جدول رقم (1) - ج}

1/ 1/ الاراسات العربية المرجعية:

\begin{tabular}{|c|c|c|c|c|c|c|c|}
\hline اهم النتائج & ادوات جمع البيانات & العينة & المنهج & هدف البحث & عنوان البحث & اسم الباحث & 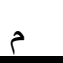 \\
\hline 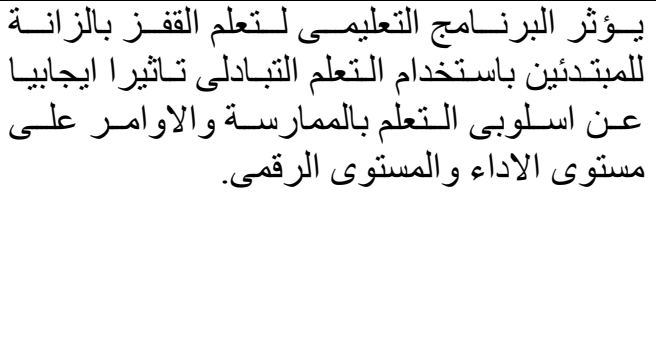 & 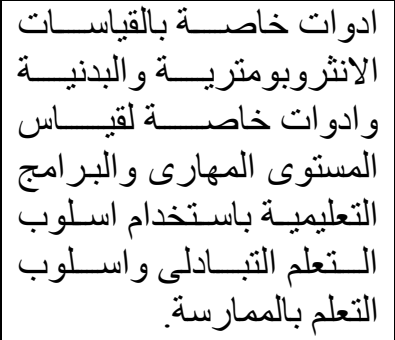 & 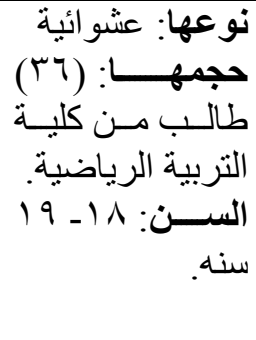 & 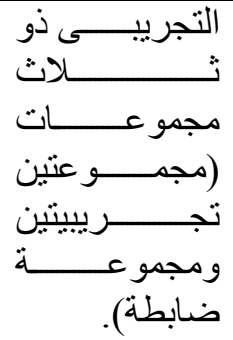 & 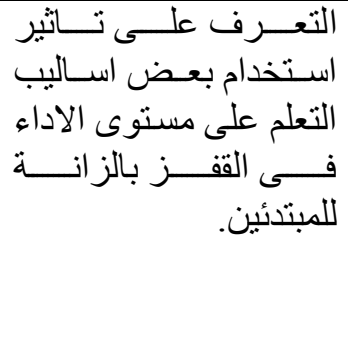 & 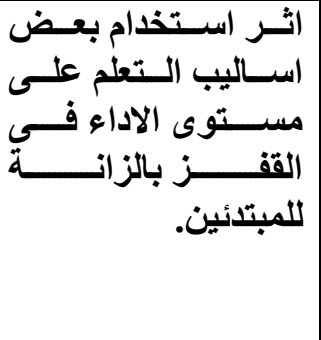 & 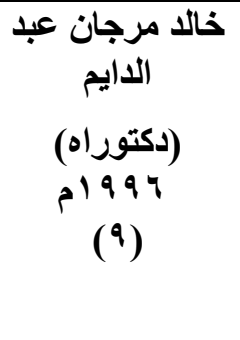 & 1 \\
\hline 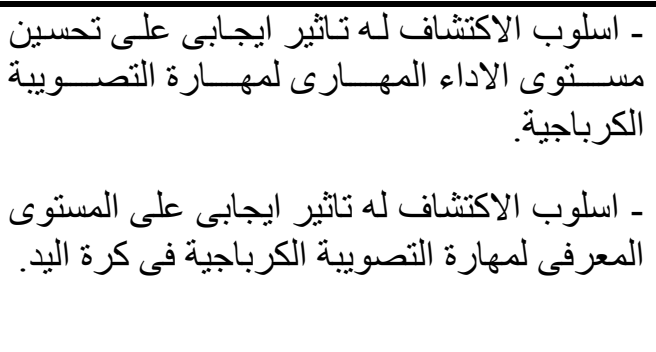 & 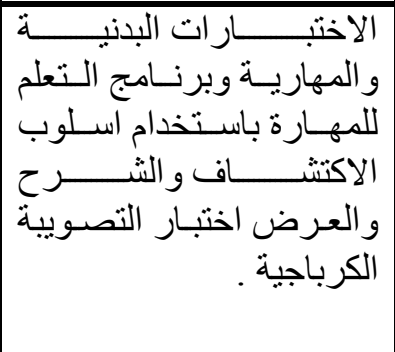 & 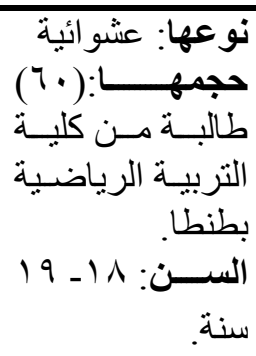 & 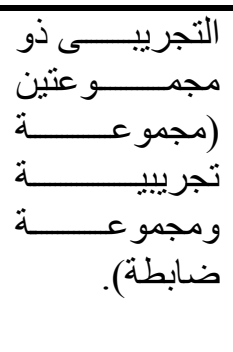 & 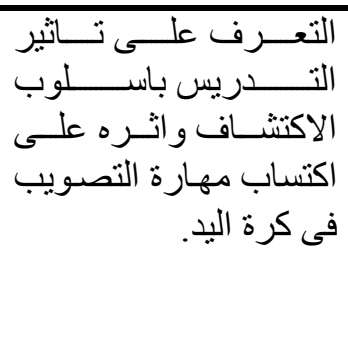 & 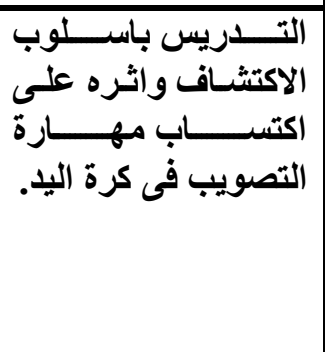 & زينب اسماعيل & $r$ \\
\hline 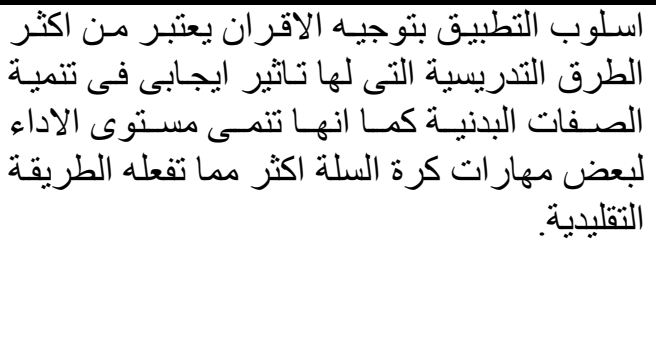 & 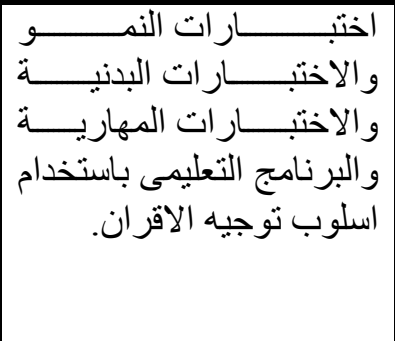 & 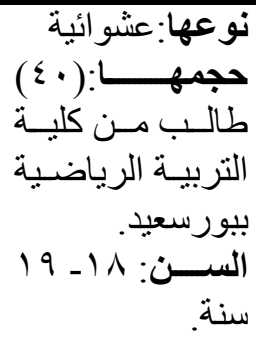 & 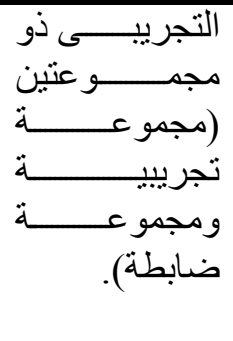 & 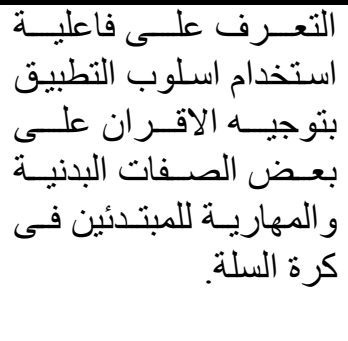 & 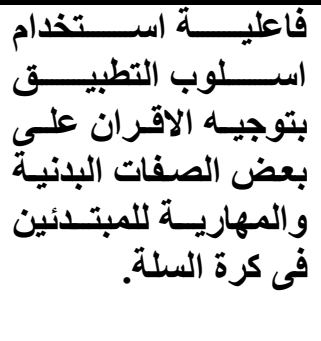 & 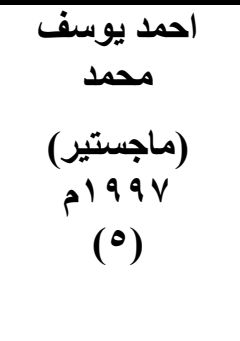 & $r$ \\
\hline
\end{tabular}


تابع جدول رقم (1) الدراسات العربية المرجعية

\begin{tabular}{|c|c|c|c|c|c|c|c|}
\hline اهم النتائج & ادوات جمع البيانات & العينة & المنهج & هدف البحث & ان ان الب & اسم الباحث & م \\
\hline 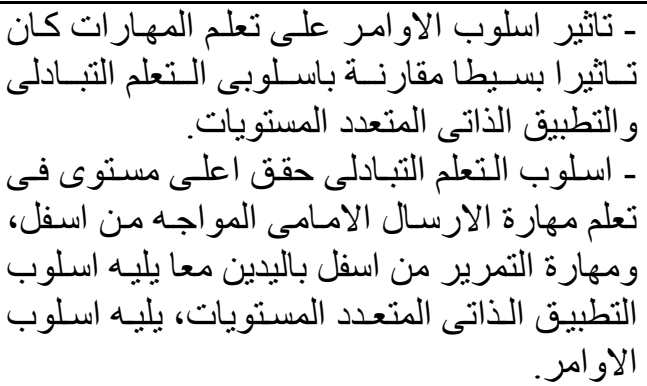 & 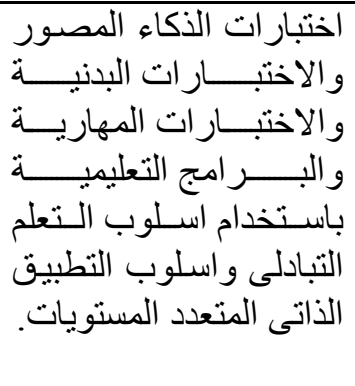 & 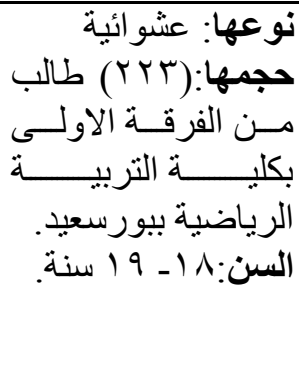 & 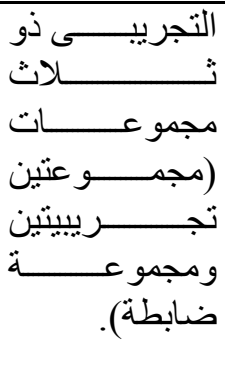 & 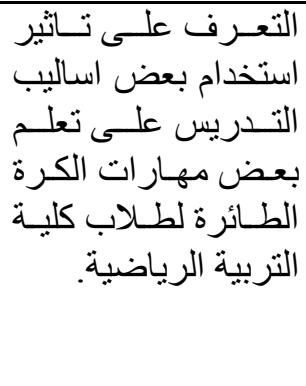 & 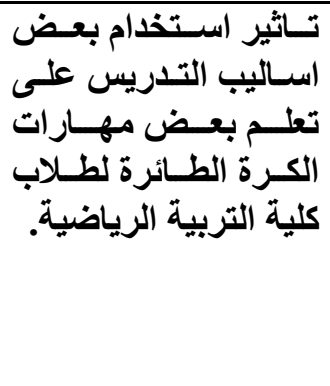 & (الموافى السيد & $\varepsilon$ \\
\hline 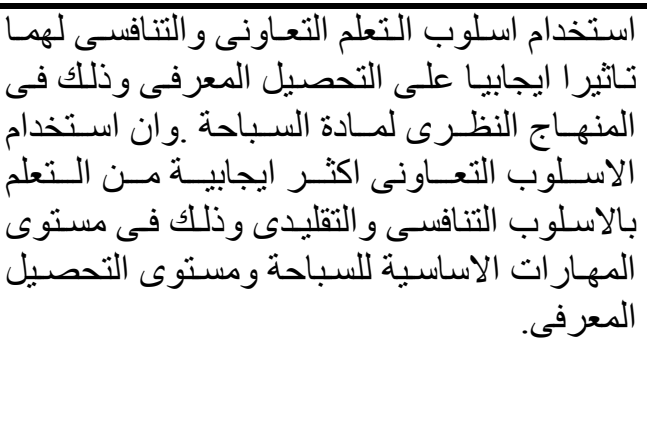 & 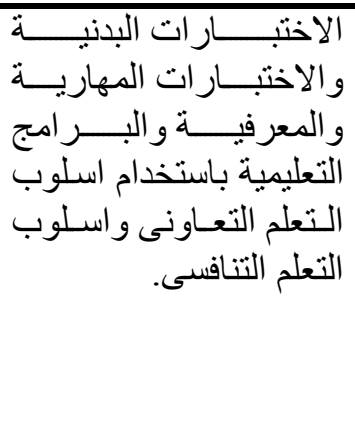 & 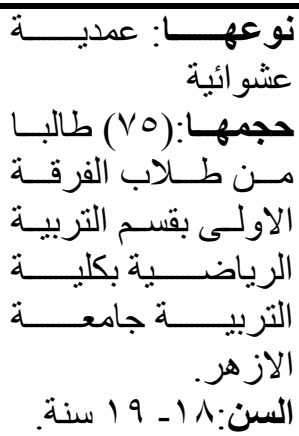 & 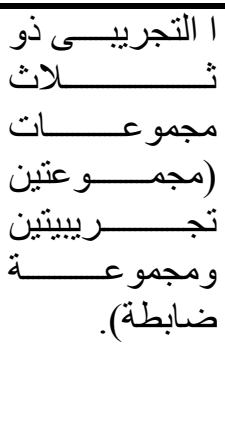 & 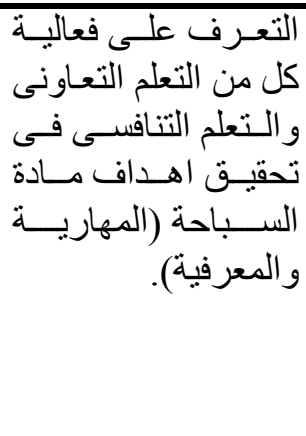 & بعضض فاحة. & 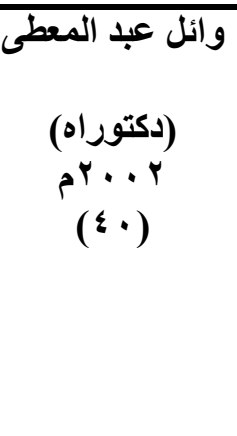 & 0 \\
\hline 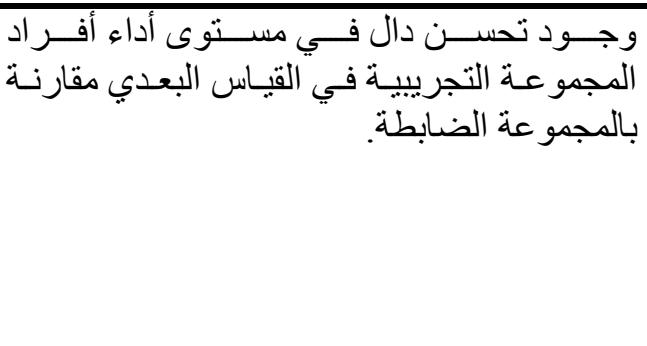 & 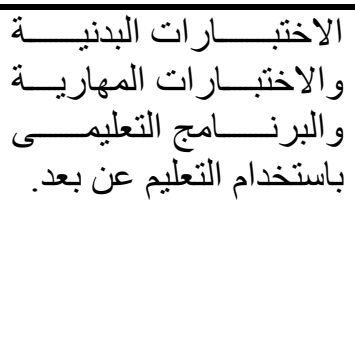 & 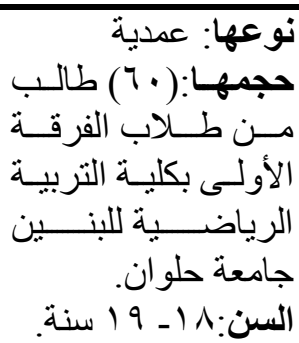 & 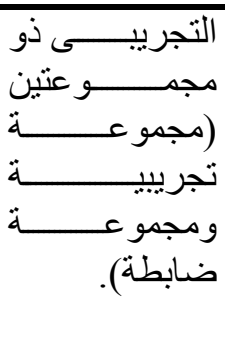 & 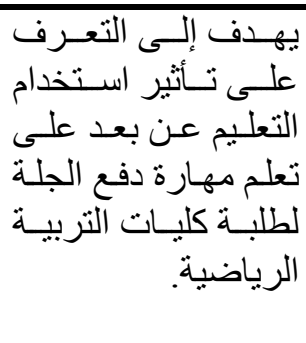 & 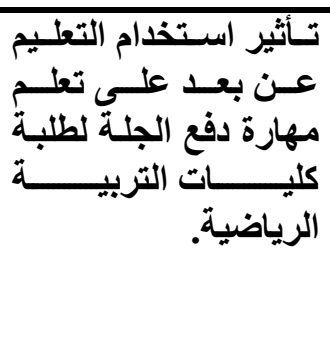 & 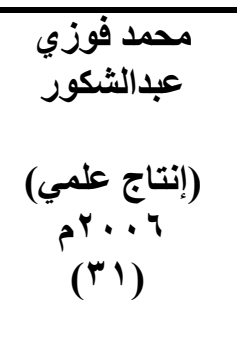 & 7 \\
\hline
\end{tabular}


تابع جدول رقم (1) الدراسات العربية المرجعية

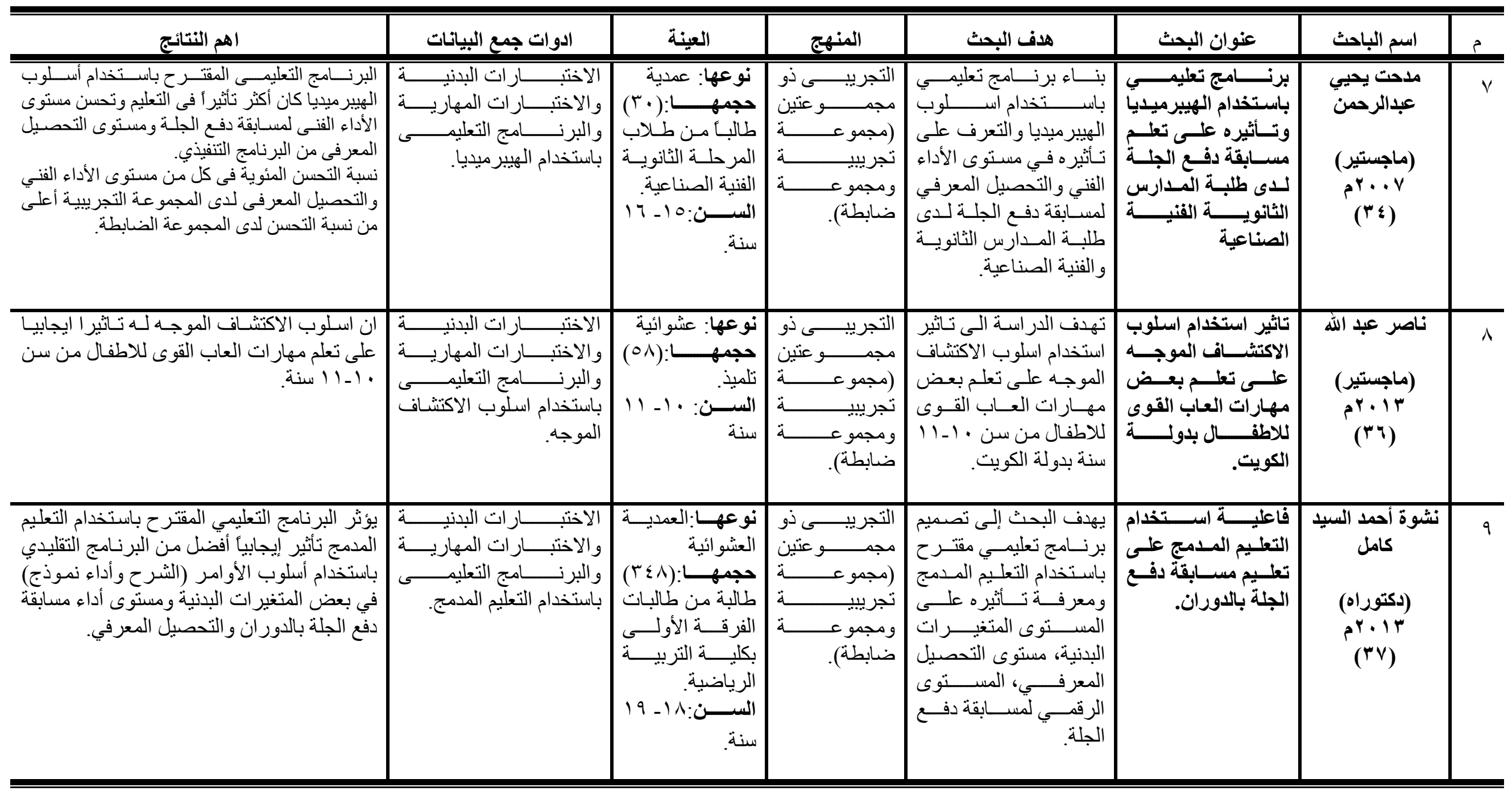


تابع جدول رقم (1) الدراسات العربية المرجعية

\begin{tabular}{|c|c|c|c|c|c|c|c|}
\hline اهم النتائج & ادوات جمع البيانات & العينة & المنهج & هدف البحث & ن البحث & اسم الباحث & م \\
\hline 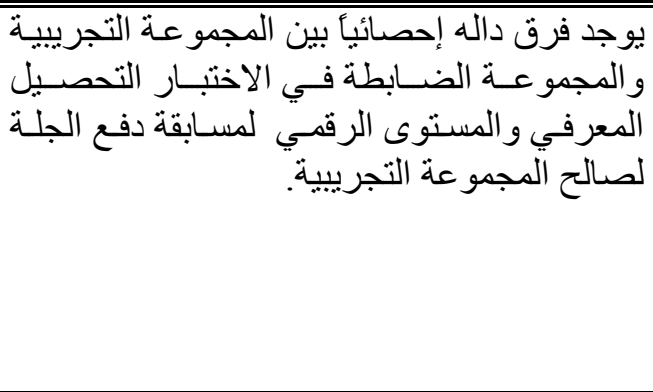 & 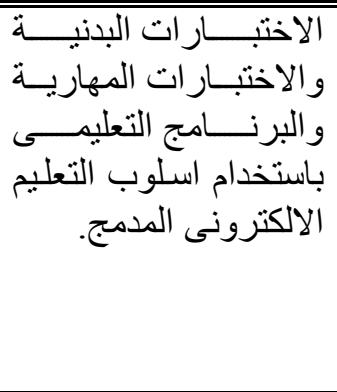 & 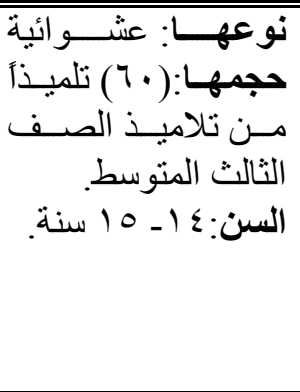 & 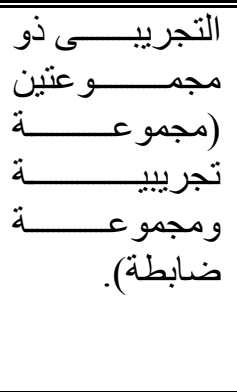 & 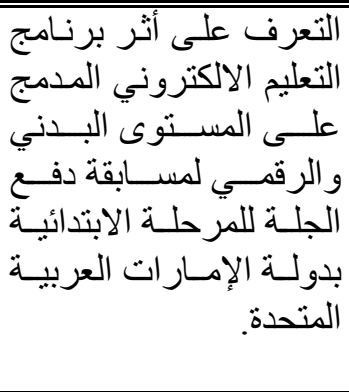 & 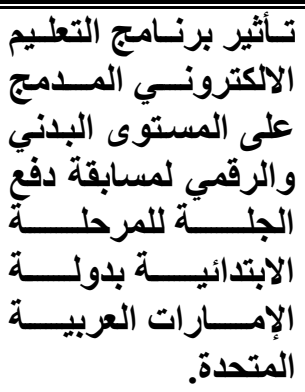 & 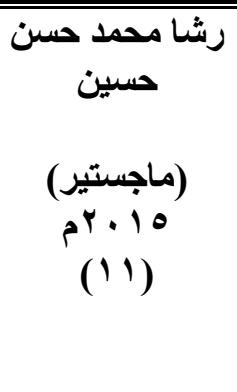 & 1. \\
\hline 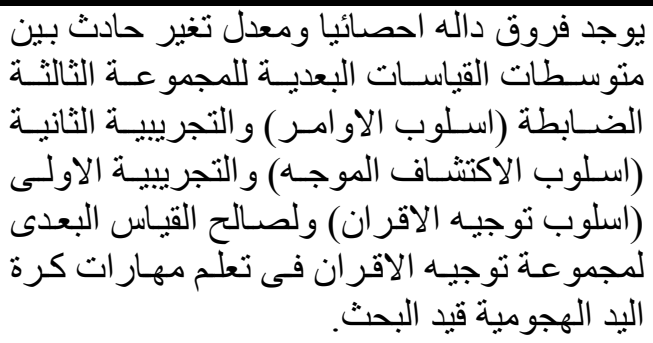 & 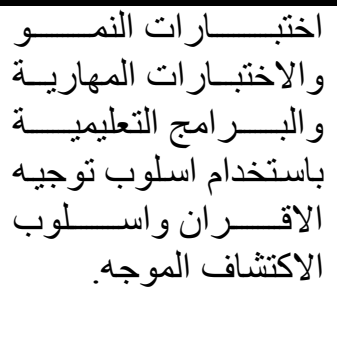 & 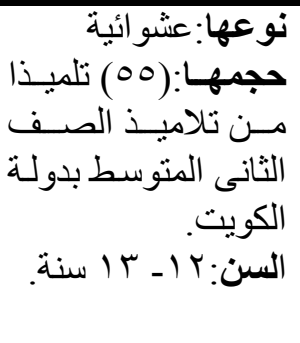 & 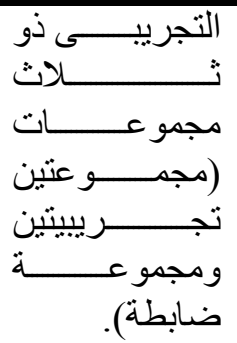 & 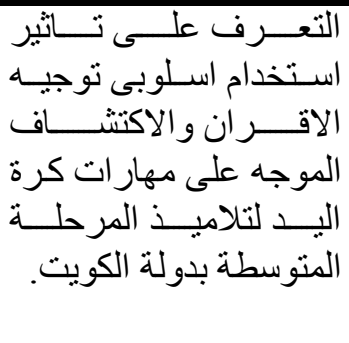 & 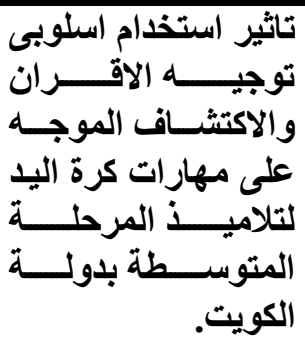 & 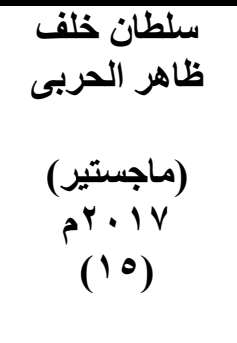 & 11 \\
\hline
\end{tabular}


جدول رقم (ץ) الدراسات الانجليزية المرجعية

r/r/r الداراسات الاتجليزية المرجعية:

\begin{tabular}{|c|c|c|c|c|c|c|c|}
\hline أهم النتائج & ادوات جمع البيانات & العينة & المنهج & هدف البحث & ' & اسم الباحث & p \\
\hline 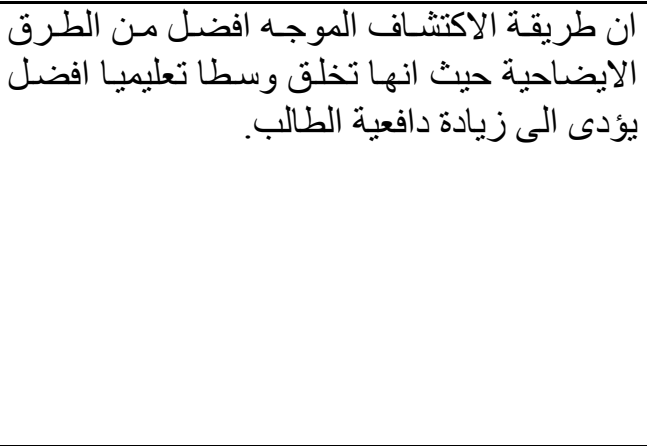 & 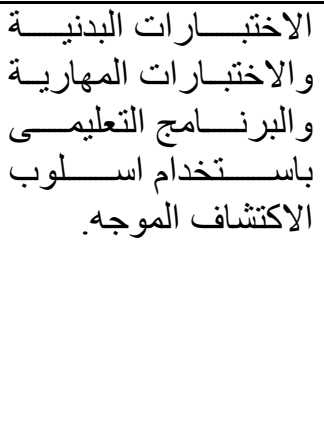 & 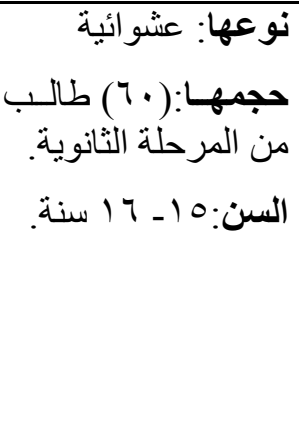 & 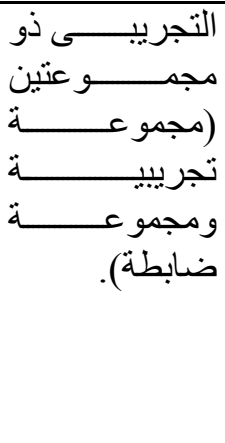 & 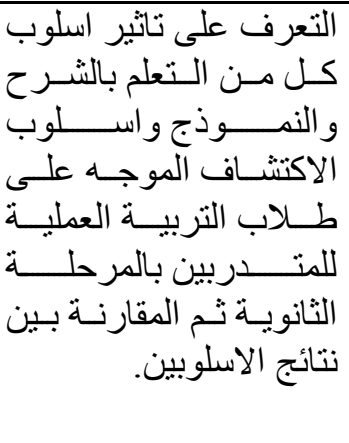 & 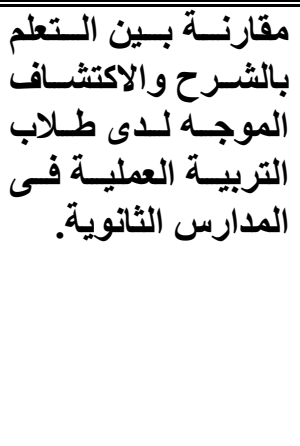 & 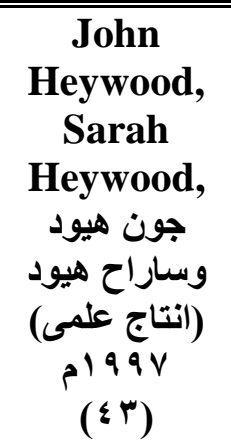 & 1 \\
\hline 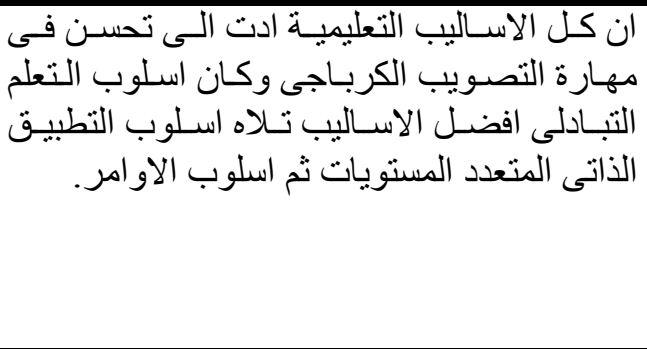 & 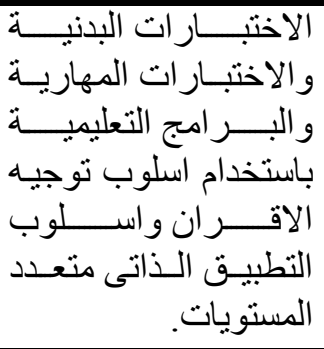 & نوعها: عشو ائية & 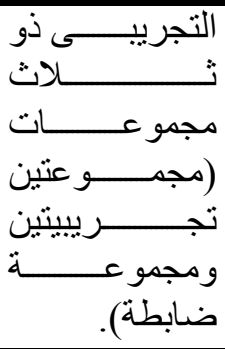 & 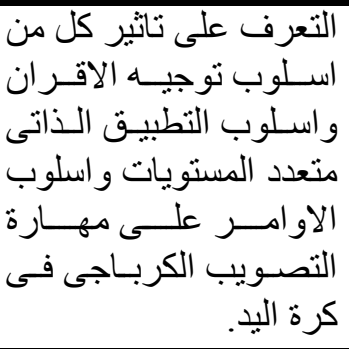 & 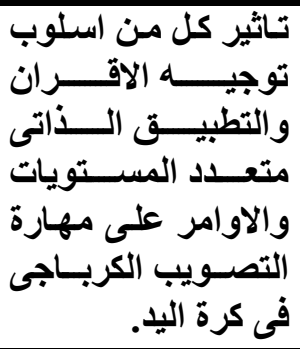 & 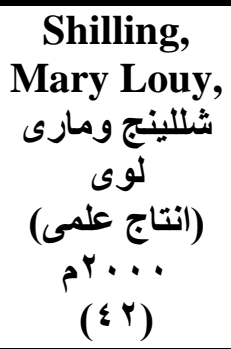 & $\bar{r}$ \\
\hline
\end{tabular}


الاستفادة من الار اسات السابقة المرجعية

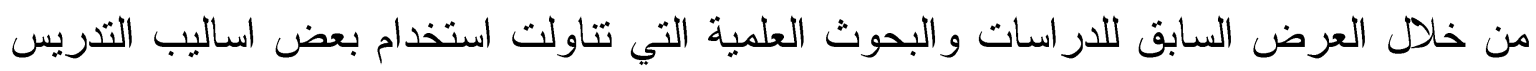

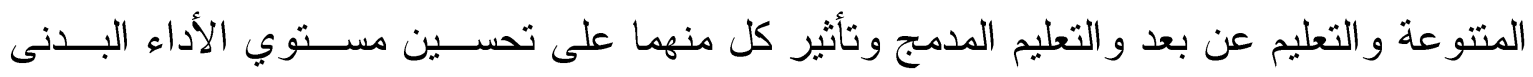

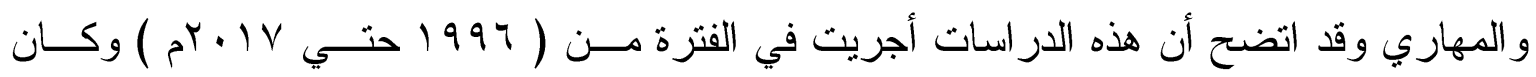

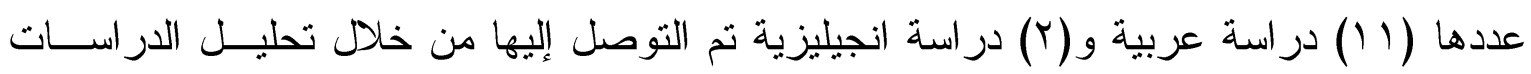

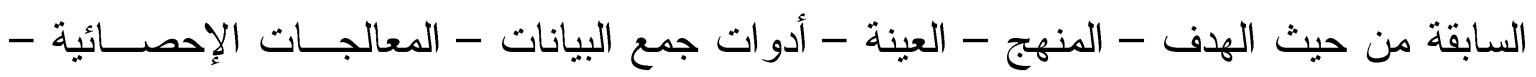

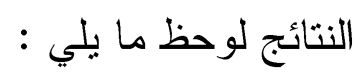

\section{من حيث الههف :-}

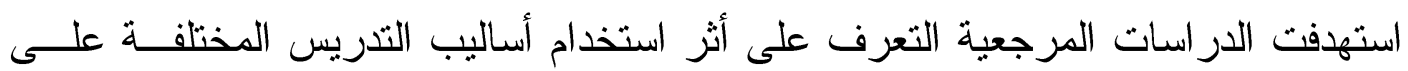

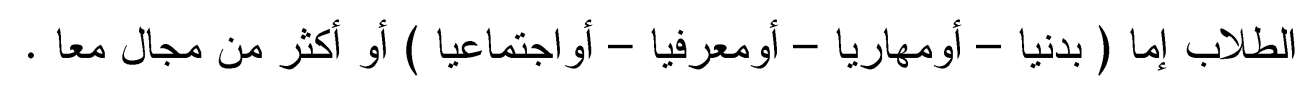

من حيث المنهج :

إتفقت جميع الدراسات المرجعية العربية والأجنبية على إستخدام المنهج التجريبى باعنباره

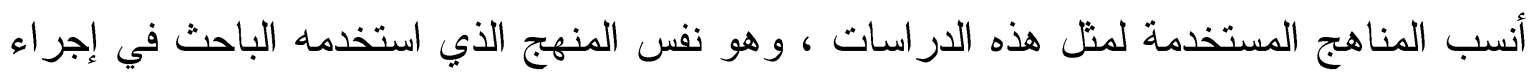

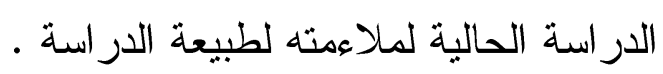

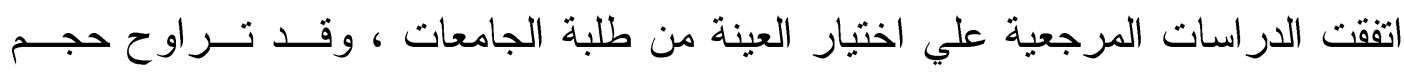

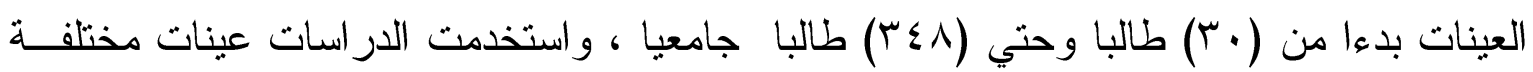

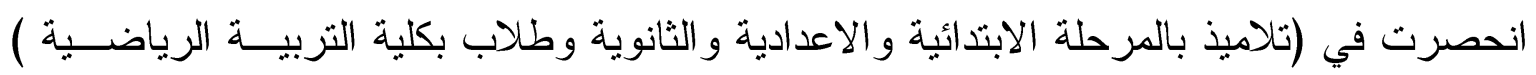

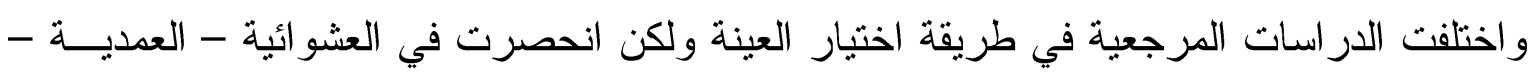

$$
\text { أدوات جمع البيانات :- العمو ائية }
$$

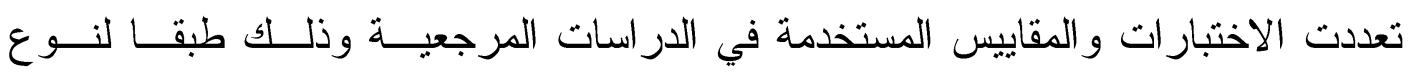

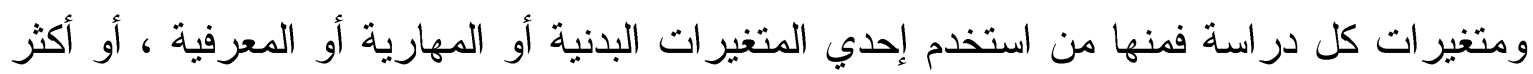

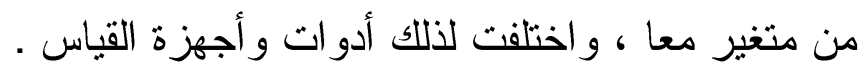


تعددت واختلفت نتائج الدراسات المرجعية وتأثير كل منها علي المتغيرات الخاصة بكـلـل دراسة ، فمنها من توصل إلي تفوق أسلوب التطبيق بتوجيه المعلم (الممارسة)علي أسلوبي التطبيق

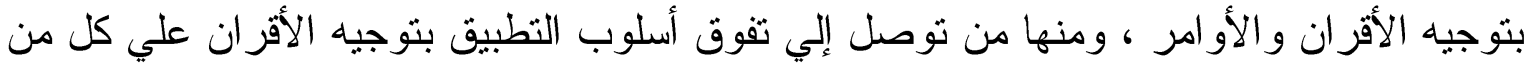

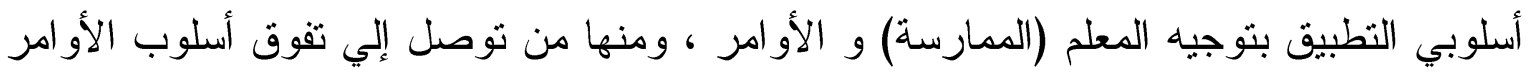

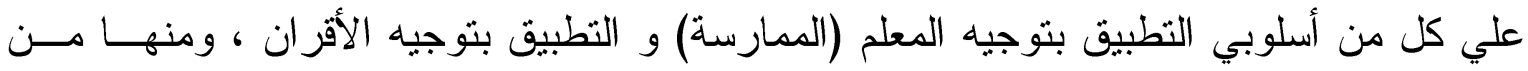
توصل إلي عدم وجود فروق دالة بين الأساليب الثلاثة . وقد استفاد الباحث من خلال اطلاعه علي الدراسات المرجعية فى تحديد الأهداف وصباغة الفروض وتحديد المنهج و العينة والأدوات و الأسلوب الإحصائى وكيفية عرض النتائج ومناقثــتـها كما استفاد الباحث من الدراسات المرجعية أيضا فى الآتى : - تحديد الخطوات المتبعة فى إجر اءات البحث فى النواحى الفنية والإدارية . - تحديد مكان تتفيذ البرنامج وشروطه . - تحديد الإختبار ات الخاصة بالبحث. - وجيه الباحث لأهم المر اجع المرتبطة بالبحث وكيفية بناء الإطار النظرى . - الاستفادة من نتائج الدراسات السابقة فى مناقثة نتائج الدراسة الحالية.

\section{إجراعات البحث}

منهج البحث

استخدم الباحث المنهج التجريبي وذلك لملائمته لطبيعة هذا البحث ، وقد اسـتعان الباحــث

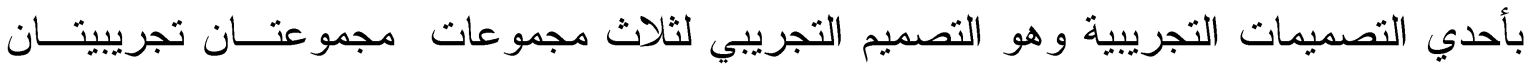
و الثالثة مجموعة ضابطة بتطبيق القياسات القبلية و البعدية للثلاث مجمو عات.

مجتمع وعينة البحث

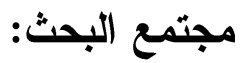

تم تحديد مجتمع البحث من فصول الصف الخامس الابتدائى بمدرسة الصوه الابتدائية بادارة

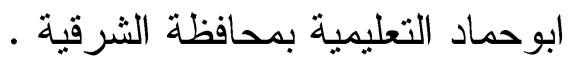




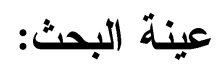

تم اختيار عينة البحث بالطريقة العمدية من تلاميذ الصف الخامس الابتدائى بمدرسة الصــوه

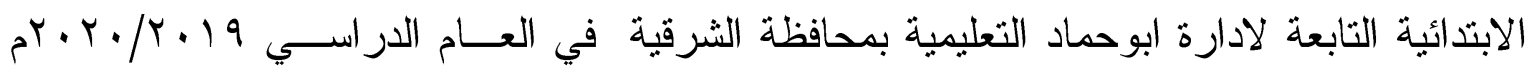

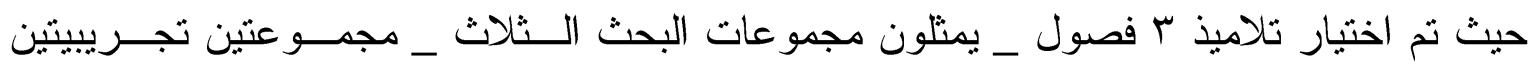

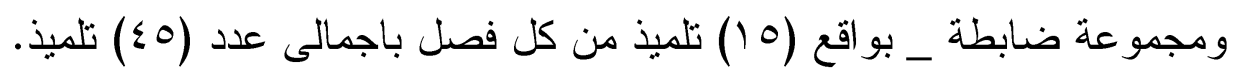
اضافة لاختيار عدد (• () تلاميذ من فصل اخر خلاف العينة من الفصول السابقة لاجر اء الدراسة

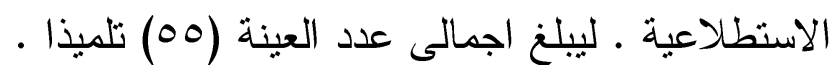
ويوضح الجدول توصيف عينة البحث الكلية (الأساسية - الاستطلاعية)

جلول (r)

توصيف عينة البحث

\begin{tabular}{|c|c|c|c|c|}
\hline عينة البحث & التجريبية البثانية & التجريبية البحثلى & الاستطلاعية البحث & البحثة \\
\hline العدد & العدد & العدد & العدد & \multirow{2}{*}{00} \\
\hline 10 & 10 & 10 & 1. & \\
\hline
\end{tabular}

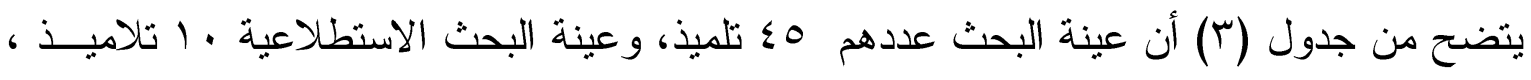

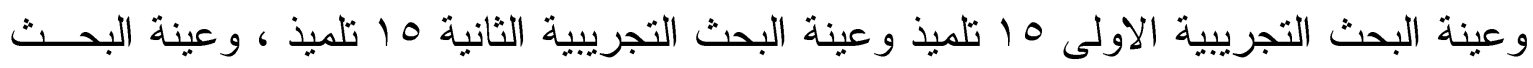

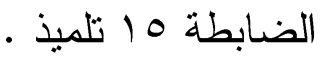

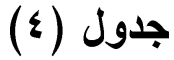

إعتدالية توزيع أفراد عينة البحث في المتغيرات قيل الدراسة

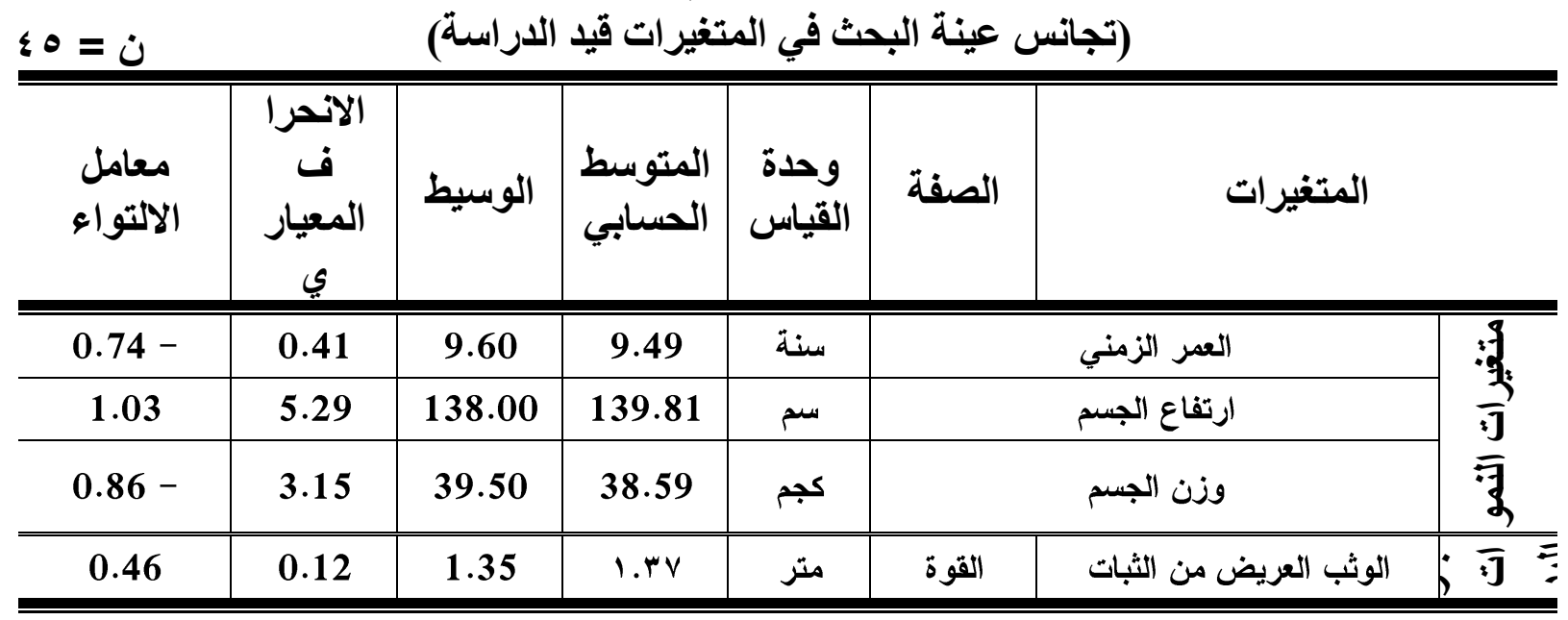




\begin{tabular}{|c|c|c|c|c|c|c|}
\hline & & & & & العضلية & \\
\hline 0.95 & 0.62 & 6.42 & 6.61 & ثانية & السرعة & عدو · سّم من البدء العالي \\
\hline 0.74 & 0.89 & 8.00 & 8.22 & 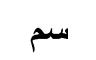 & المرونة & ثني الجذع أماماً أسفل \\
\hline 0.68 & 0.57 & 5.73 & 5.85 & ثانية & الرشاقة & الجري الزجزاجى \\
\hline 1.15 & 1.87 & 18.00 & 18.72 & عرات & التحمل & الجزي في المكان • بث \\
\hline 0.96 & 0.17 & 0.17 & 1.60 & 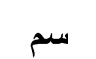 & & اختبار الوثب الطو \\
\hline
\end{tabular}

يبين جدول (ع) أن قيم معاملات الالتواء تتحصر ما بين (-1 (

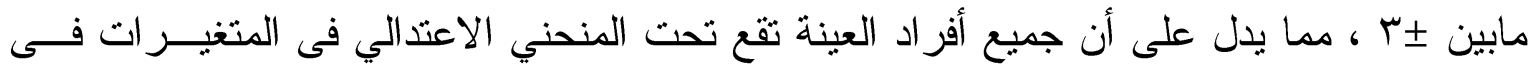
المتغيرات النمو و البدنية والمهارية مما يشير إلي تجانس أفر اد عينة البحث .

\section{تكافؤ عينة البحث: :}

قام الباحث باجر اء التكافؤ بين مجموعات البحث الثلاثة( الضابطة - التجريبية الأولى - التجريبية الثانية ) في المتغيرات البدنية و المهارية المختارة قيد البحث وذللك للتأكد من تكافؤ المجموعات في هذه المتغير ات ويعتبر هذا القياس بمثابة القياس القبلي لمجموعات البحث،كما يوضحه الجدولين كما

$$
\text { يوضحه جدول (0). }
$$

(0) جدول

تحليل التباين بين متوسطات درجات القياسات القبلية لمجموعات البحث الثلاثة فى المتغيرات البلنية واختبار الوثب الطويل قيد البحث

\begin{tabular}{|c|c|c|c|c|c|}
\hline "فيمة & متوسط & درجات الحرية & المربعوع & مصدر التباين & المتغير ات \\
\hline \multirow[t]{2}{*}{$1 . \leqslant \wedge$} & .11 & r & .. ro & بين المجموعات & \multirow{2}{*}{ الوثب العريض من } \\
\hline & $\cdots \cdots$ & ov & . & داخل المجموعات & \\
\hline \multirow[t]{2}{*}{.91} & צח & r &.$v r$ & بين المجموعات & \multirow{2}{*}{ عدو · لَم من البدء } \\
\hline &.$\varepsilon$ & ov & r. YY & داخل المجموعات & \\
\hline \multirow[t]{2}{*}{.$\wedge \wedge$} & .70 & $r$ & . & بين المجموعات & \multirow{2}{*}{ تُي الجذع أماماً أسفل } \\
\hline & . & or & $\leqslant 1.90$ & داخل المجموعات & \\
\hline
\end{tabular}




\begin{tabular}{|c|c|c|c|c|c|}
\hline \multirow[t]{2}{*}{. $.9 r$} & $\cdots 9$ & r &.+11 & بين المجموعات & \multirow{2}{*}{ الجري الزجزاجى } \\
\hline & $\cdot .1 \cdot 1$ & OV & $0 . \vee \wedge$ & داخل المجموعات & \\
\hline \multirow[t]{2}{*}{..$\Sigma \wedge$} & r.r & r & 7.01 & بين المجموعات & \multirow{2}{*}{ الجري في المكان } \\
\hline & T.V. & or & rᄉ.. o & داخل المجموعات & \\
\hline \multirow[t]{2}{*}{ צו". } &.$r q$ & r &. .01 & بين المجموعات & \multirow[t]{2}{*}{ اختبار الوثب الطويل } \\
\hline &.$\wedge$ & ov & $\leqslant 0 . .0$ & داخل المجموعات & \\
\hline
\end{tabular}

قيمة ف عند مستوى 0 ... =. •.

يتضح من جدول ( 0 ) عدم وجود فروق دالة إحصائيا بين مجموعات البحث الثاثثة( الضابطة التجريبية الأولى - التجريبية الثانية ) في المتغيرات البدنية و المهارية قيد البحث، حيث كانت قيم (ف ) المحسوبة أقل من قيم( ف ) الجدولية عند مستوى0.05

\section{وسائل جمع البيانات :-}

إعتمد الباحث على ثلاثة مصادر أساسية لجمع البيانات فى در استه وهى كالأتى:

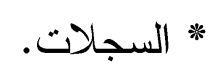

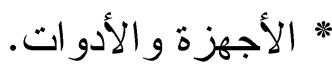

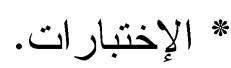

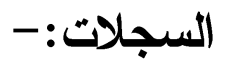

قام الباحث بإستخر اج العمر الزمنى للنالايذ من خلال السجلات الخاصة بهم كذلك لمعرفة الطلاب الباقون للإعادة لإستبعادهم من البحث وذلك لتسجيل البيانات الشخصية لهم فى إستمارة تسجيل البيانات الشخصية فى الإختبار ات قيد البحث

الأجهزة والأدوات المستخدمة فى البحث :-

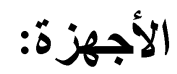

1- الريستاميتر لقياس الطول الكلى (الإرتفاع) بالسنتيمتر . r- بيز ان طبى لقياس الوزن.

الأدو ات:

اساعة إيقاف لقياس الزمن بالثو انى (لحساب بداية ونهاية الوحدة التعليمية). r- شريط قياس لقياس المسافة.

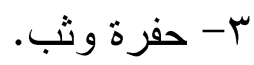




$$
\text { ؟- ؟- كامبر ا تصوير فيديو . حواجز. }
$$

V- إسطو انه (CD) حيث إحتوت على نماذج للنو احى الفنية لمسابقة الوثب الطويل.

$$
\text { 9-1 } 1 \text { - أقماعرة مدرجة. }
$$

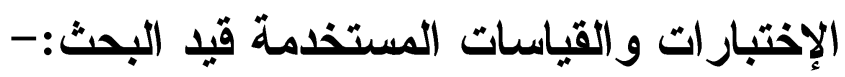

$$
\text { القياسات الاثثروبومترية:- }
$$

حيث قام الباحث بإجر اء القياسات الإنثروبومترية التالية :-

العمر : ويتم حسابه بالسنة

الطول: ويقاس بالسنتيمترات

المزن: الميقاس بالكيلو جرام

وقد تأكد الباحث من صلاحية أجزةة القياس المستخدمة وهى (الميزان الطبى - جهاز الريستاميتر) الإختبار ات للصفات البدنية لمسابقة الوثب الطويل :-

قام الباحث بإجر اء مقابلات شخصية مع مجموعة من السادة الخبر اء فى مجال مسابقات الميدان

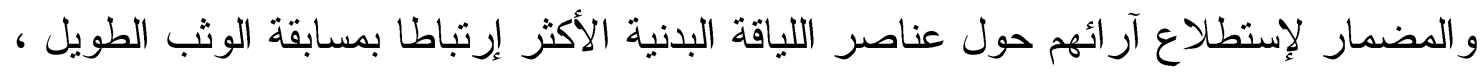

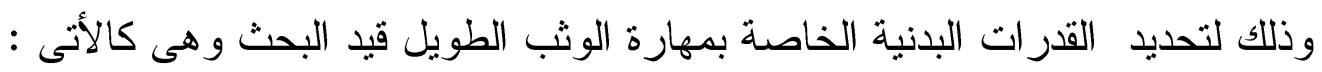
( القوة المميزة بالسرعة - السرعة - تحمل القوة - الرشاقة - المرونة)

وبناء على ما سبق عرضة من نتائج تم الإسترشاد برأى السادة المشرفين وقد رأوا الإكتفاء بإختبار و احد لكل صفة من الصفات البدنبة الخاصة بمهارة الوثب الطويل. 
عرض ومناقشة النتائج •

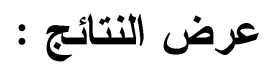

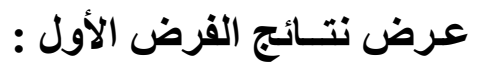

\section{جدول (9)}

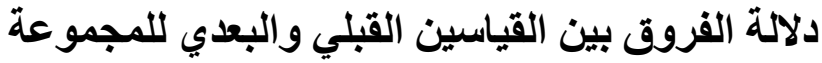

\begin{tabular}{|c|c|c|c|c|c|c|}
\hline \multicolumn{7}{|c|}{ الضابطة ( اسلوب الاوامر ) في اختبار الوثب الطويل قيد البحث } \\
\hline \multirow{2}{*}{ قالحسموبة (ت) } & \multicolumn{2}{|c|}{ القياس البعدي } & \multicolumn{2}{|c|}{ القياس القبلي } & \multirow{2}{*}{ القياس } & \multirow[b]{2}{*}{ 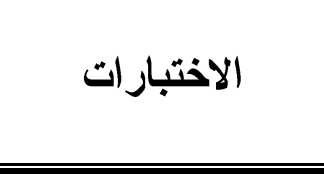 } \\
\hline & المعياري & الحستوسطي & المعياري & الحسابي & & \\
\hline 2.60 & 0.13 & 1.55 & 0.16 & 1.40 & سم & اختبار الوثب الطويل \\
\hline
\end{tabular}

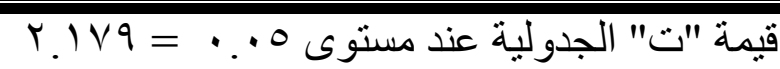

يتضـح من جدول (9) وجود فروق دالـة إحصـائية بين متوسطي القياسين القبلي و البعدى القي

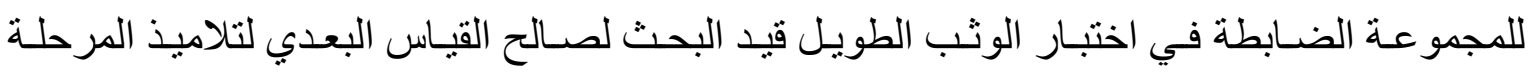
الابتدائية .

عرض نتـائج الفرض الثانى :

$$
\text { جدول (· (1) }
$$

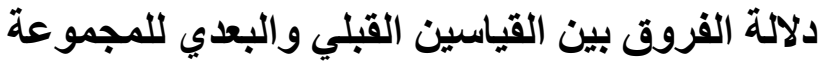

\begin{tabular}{|c|c|c|c|c|c|c|}
\hline \multirow{2}{*}{ قالمسيوبة (ت) } & \multicolumn{2}{|c|}{ القياس البعدي } & \multicolumn{2}{|c|}{ القياس القبلي } & \multirow{2}{*}{ والقياس } & \multirow[b]{2}{*}{ الاختبار ات } \\
\hline & المعياري & الحستبي & المعياري & الحسابي & & \\
\hline 4.45 & 0.11 & 1.78 & 0.16 & 1.60 & 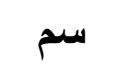 & اختبار الوثب الطويل \\
\hline
\end{tabular}

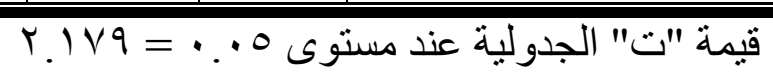

يتضح من جدول (• ( ) وجود فروق دالة إحصائية بين متوسطي القياسين القبلي و البعدى للمجموعة التجريبية الاولى (الاسلوب التبادلى ) في اختبار الوثب الطويل قيد البحث لصـالح القياس 
عرض نتـائج الفرض الثالث : ع

$$
\text { جدول (11) }
$$

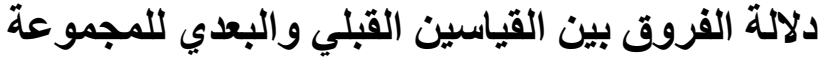

$$
\text { التجريبية الثانية(اسلوب الاكتثاف الموجه )في اختبار الوثب الطويل قيد البحث }
$$

\begin{tabular}{|c|c|c|c|c|c|c|}
\hline \multirow{2}{*}{ قالمحسوبة (ت) } & \multicolumn{2}{|c|}{ القياس البعدي } & \multicolumn{2}{|c|}{ القياس القبلي } & \multirow{2}{*}{ القياس } & \multirow{2}{*}{ الاختبار ات } \\
\hline & المعياري & الحستابي & المعياري & الحسابي & & \\
\hline 2.65 & 0.14 & 1.65 & 0.18 & 1.57 & سم & اختبار الوثب الطويل \\
\hline
\end{tabular}

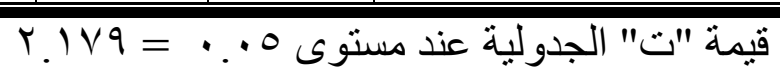

يتضح من جدول ( (1) ) وجود فروق دالة إحصائية بين متوسطي القياسين القبلي و البعدى

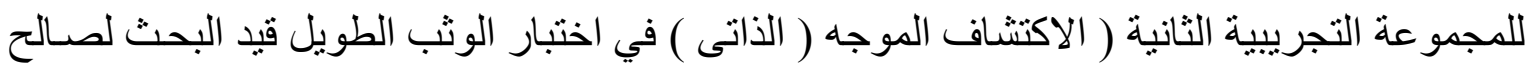
القياس البعدي لتلاميذ المرحلة الابتدائية .

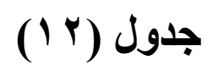

\begin{tabular}{|c|c|c|c|c|c|}
\hline قيمة "ف" & متوسط & درجات & المجبعوت & مصدر التباين & الاختبارات \\
\hline \multirow[t]{2}{*}{$* 7 . \leq 0$} & Ir.r & r & $1 . r V$ & بين المجمو عات & \multirow{2}{*}{ اختبار الوثب الطويل } \\
\hline & $1 \leq .90$ & or & 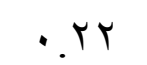 & داخل المجمو عات & \\
\hline
\end{tabular}

تحليل التباين بين مجموعات البحث الثلاث و التي استخدمت الأساليب التالية ( توجيه الاقران - التان الاكتثاف الموجه - اسلوب الاوامر ) في اختبار الوثب الطويل قيد البحث في القياسات البعدية 
مناقثشة النتائج .

مناقثة نتائج الفرض الأول والأي ينص " توجد فروق دالة إحصائيا بين متوسط نتــائج القياسيين القبلي والبعدي للمجموعة الضابطة ( اسلوب الاوامر) في تعليم مهارة الوثب الطويل لصالح القياس البعدي لتلاميذ المرحلة الابتدائية.

أظهرث نتائج جدول (9) وجود فروق دالة إحصائية بين منوسطي القياسين القبلي و البعدي للمجموعة الضابطة في اختبار الوثب الطويل لصالح القياس البعدي • ويرجع الباحث ذلك التحسن إلى الدور الايجابي الذي يقوم به المعلم أثناء تعلم مهارة الوثب الطويل قيد البحث باستخدام أسلوب الأوامر والذي يعتمد على الشرح اللفظي من قبل المعلم للمهارة ووصفه وصفا دقيقًا بالإضافة إلى عرض نموذج عملي للمهارة المتعلمة، هذا بجانب تقديم التغذية المرتدة والتقويم المستمر أثناء وبعد أداء مهارة الوثب الطويل قيد البحث.

و هذا ما يؤكده سعيد الشاهد (9 9V (م) بان التدريس باسلوب الاو امر ( الثــرح اللفظـى و النموذج) و استمر ار الاداء و التكرار و اصلاح الاخطاء للتلامبذ من المعلم يوفر للتناميــذ فرصــة جيدة للتعلم ويؤثر ايجابيا على كفاة الاداء المهارى (س ا:ب و ( ). وما تؤكده عفاف عبدالكريم ( •99 ام) بان اسلوب الاوامر يعتمد على العلاقة المباشــرة بين التناميذ و المعلم حيث تبنى استجابات التلاميذ على اوامر المعلم (•r: • 9). وبذلك يتحقق الفرض الأول الذي ينص " توجد فروق دالة إحصائيا بين متوســط نتــائج القياسيين القبلي والبعدي للمجموعة الضابطة في تعليم مهارة الوثب الطويل لصالح القياس البعدي لتلاميذ المرحلة الابتدائية .

مناقشة نتائج القرض الثاني والأي ينص توجد فروق دالة إحصائيا بين متوسط نتائج القياسيين القبلي والبعدي للمجموعة التجريبة الاولى في تعليم مهارة الوثب الطويل لصالح القياس البعـــي لتلاميذ المرحلة الابتدائية. أظهرت نتائج جدول ( • () وجود فروق دالة إحصائية بين متوسطي القياسـين القبلـي و البعـدى للمجموعة التجريبية الاولى في اختبار الوثب الطويل لصالح القياس البعدي حيث بلغت قيمــة (ت) المحسوبة (Y.OV) في القياس (القبلي/البعدي) وهي أكبر من قيمة "ت" الجدولية عند مستوى 0 ... 
(Y. V V9) مما يدل علي وجود فروق دالة إحصائية بين متوسطي القياسين القبلي و البعدى لصــالح القياس البعدي .

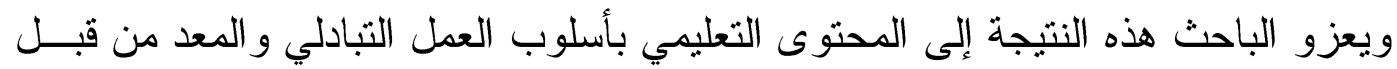

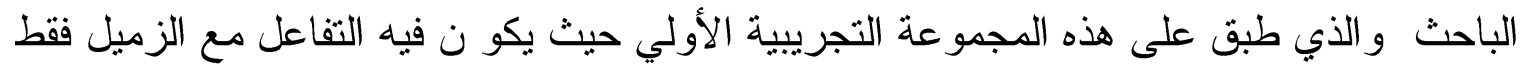

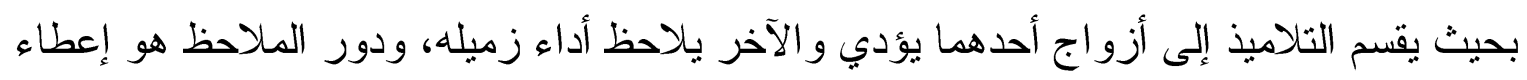

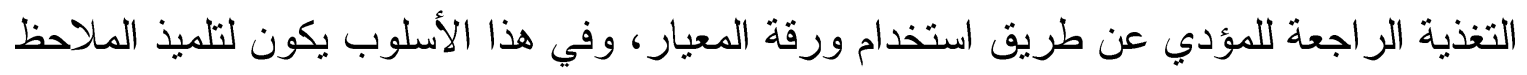

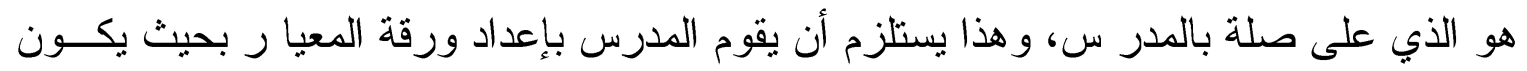
هناك تسلسل في هذه شرح و عرض الأداء بحيث تقود التلميذ إلى الهدف النهائي من عملية التعلم.

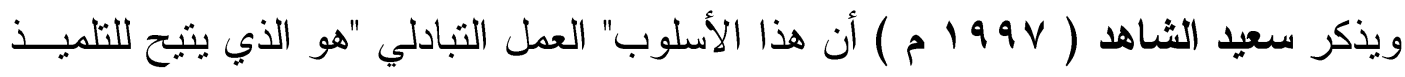

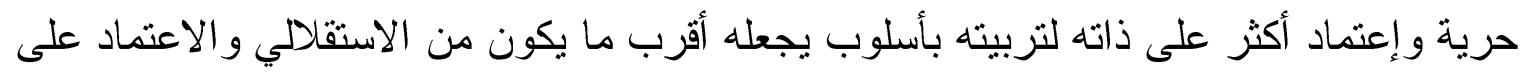

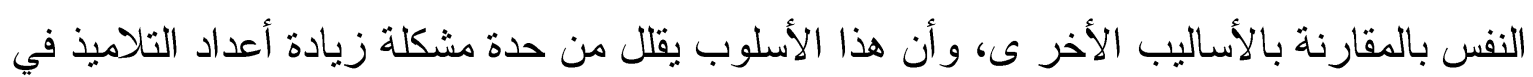

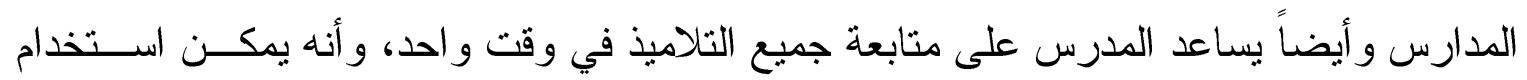

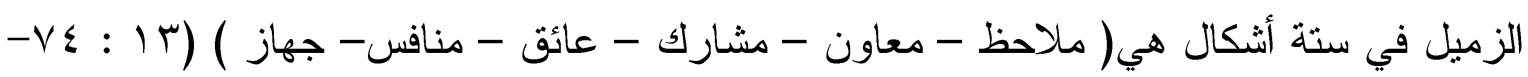

كما تضيف عفاف عبد الكريم ( \&99 19 م ) أن المعلم يتخذ جميــع القــرارات الخاصـــة

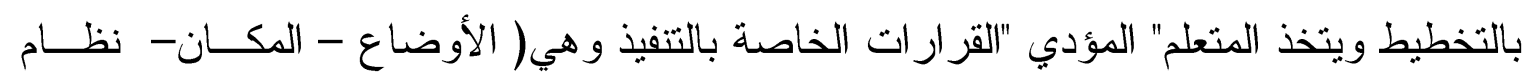

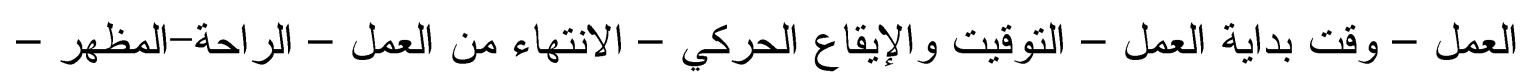

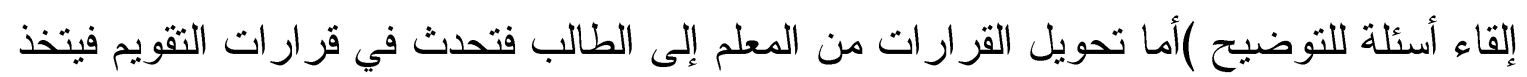
الطالب الملاحظ قرار ات التغذية الر اجعة . (19 : 111)

وبذلك يتحقق الفرض الثاني الذي ينص علي " توجد فروق دالة إحصــائيا بــين متوســ نتــائج

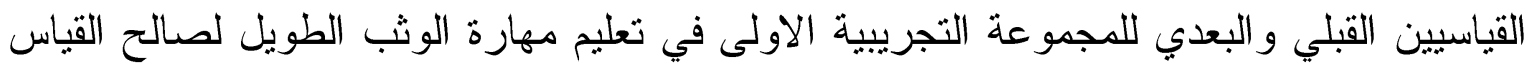
البعدي لتلامبذ المرحلة الابتدائية .

مناقشة نتائج الفرض الثالث والأي ينص " توجد فروق دالة إحصائيا بين متوسط نتـائج

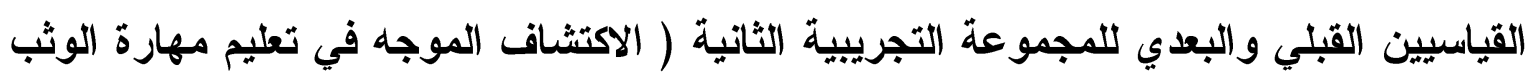
الطويل لصالح القياس البعدي لتلاميذ المرحلة الابتدائية . 
أظهرت نتائج جدول (1) (1) وجود فروق دالة إحصائيا بين متوسط نتائج القياسيين القبلـي

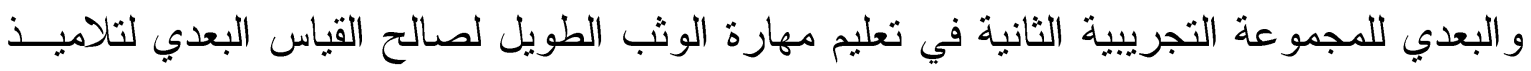

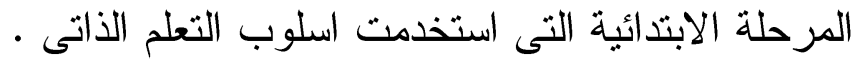

ويرجع الباحث تللك النتيجة إلى تأثير المحتوى التعليمي المقترح بإستخدام أسلوب الـتـعلم الذاتي و الذي يعتمد على قيام الباحث بتصميم ورقة معيا ر تتضمن مجموعة من الصور المتسلسلة

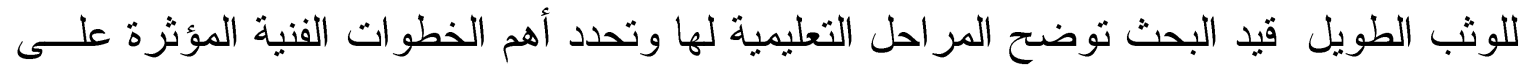
أداء المهارة بالإضافة إلى تدريبات و أسئلة للتقويم على كل مهارة، وبالتالي تساعد الورقة التعليمية

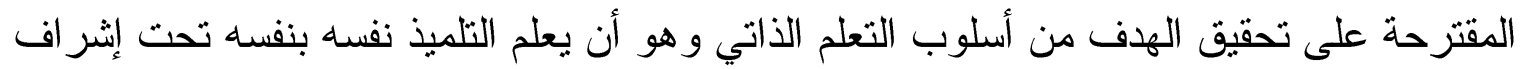
وتوجيه المدرس.

ويؤكد الباحث أن التعلم الذاتي يهدف إلى الاهتمام بالطالب و التركيز عليه في عملية التعليم

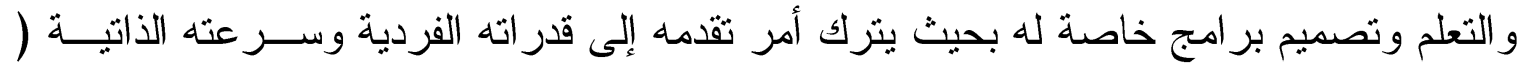
الخطر الذاتي، التتوع ) كما يتطلب توفير سلسلة من الأهداف السلوكية و اقتر اح الأنشطة التعليمية

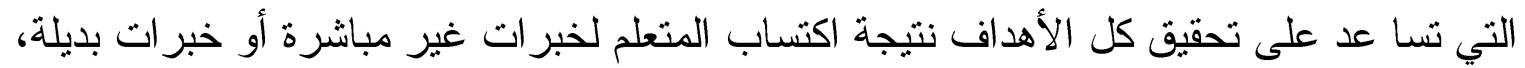
ويتطلب أيضا توفير المواد التعليمية والمصادر التي يحتاجها الطالب.

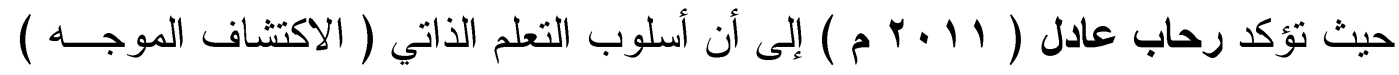

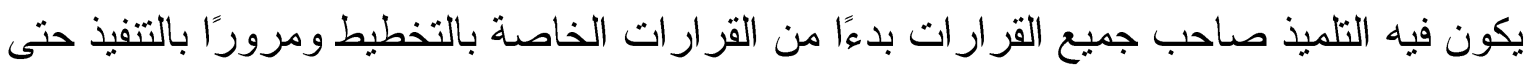

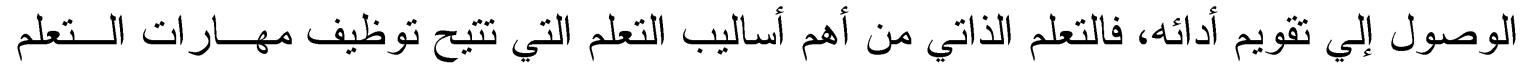
بفاعلية عالية مما يسهم في تطويز الإنسان سلوكيا ومعرفيا ووجدانيا، وهو نمط من أنماط الــتعلم

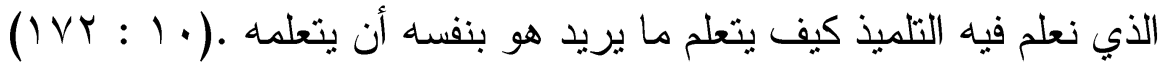

ويضيف محمد خميس ونايف سعاد ة ( 9 . . Y م ) أن المبادرة للفرد المتعلم أثناء الــتعلم

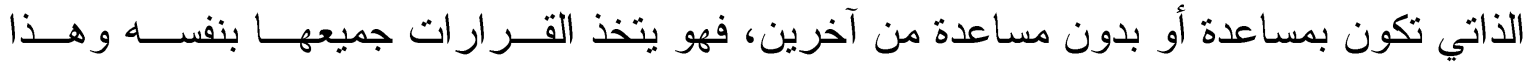
الأسلوب لا يطبق داخل الصفوف الدراسية، و إنما بطبق حين يتولى المتعلم تعليم نفسه بنفسه، وفيه

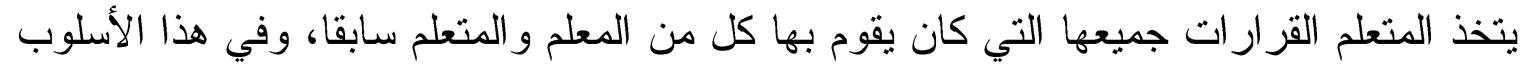

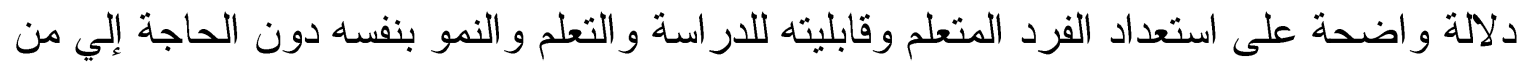


1-وجود فروق دالة احصائيا بين متوسطات القياسات القبلية والبعدية ولصالح القياسات البعدية للمجموعة الضابطة باستخدام اسلوب الاوامر فى تعلم مهارة الوثب الطويل

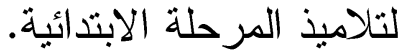
r-وجود فروق دالة احصائيا بين متوسطات القياسات القبلية والبعدية ولصالح القياسات البعدية للمجموعة التجريبة الاولى باستخدام اسلوب نوجيه الاقران فى تعلم مهارة الوثب الطويل لتلاميذ المرحلة الابتدائية. r-وجود فروق دالة احصائيا بين متوسطات القياسات القبلية والبعدية ولصالح القياسات البعدية للجموعة التجريبة الثانية باستخدام اسلوب التعلم الاكتشاف الموجه فى تعلم مهارة الوثب الطويل لتلاميذ المرحلة الابتدائية.

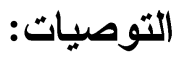

في ضوء ما اسفرت عنه النتائج يوصي الباحث بما يلي:

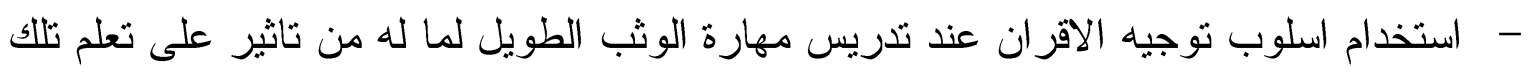

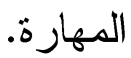

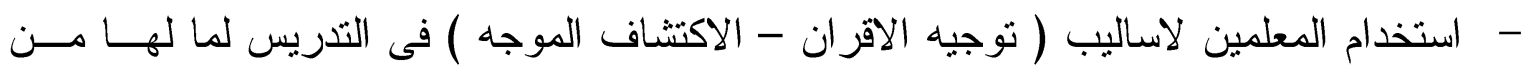
دورا فعالا وتاثير على المتعلمين لتحديث وتطوير العملية التعليمية و التربوية. - ادخال اسلوب توجيه الاقران ضمن الاساليب التى تتضمنها مناهج اعداد معلم التربية الرياضية وذللك لما لهذا الاسلوب من نتائج ايجابية متميزه اظهرتها نتائج هذا البحث. الإن.

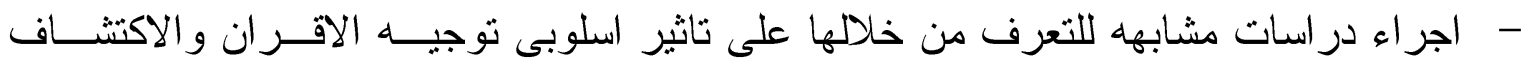
الموجه على تعلم مهارة الوثب الطويل لمر احل عمرية مختلفة. - اجر اء دراسات مماثلة على انشطة رياضية مختلفة وعلى مر احل عمرية اخرى. المراجع العربية : أبية 1. إبتهاج أحمد عبدالعال (9 (9 ام): در اسة مقارنة لتعليم بعض مهارات الهوكى منفردة أو من خلال مو اقف اللعب ، رسالة ماجستير ، كلية التربية الرياضية للبنات ، الجزيرة، جامعة

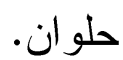
r. أبو النجا احمد عزالاين (.... (بم): الاتجاهات الحديثة فى طرق تدريس التزبية الرياضية، دار الاصدقاء، المنصورة 
r. أحمد العيد الموافى (999 (م): تاثثر استخدام بعض اساليب التدريس على تعلم بعض مهارات الكرة الطائرة لطلاب كلية التربية الرياضية، رسالة ماجستير، كلية التربية الرياضية للبنين، جامعة الزقازيق.

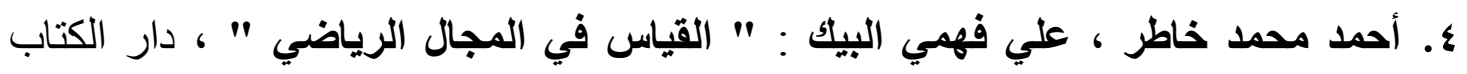

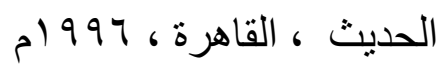

ه. أحمد يوسف محمد (99V (م)): فاعلية استخدام اسلوب التطبيق بتوجيه الاقران على بعض الصفات البدنية و المهارية للمبتدئين فى كرة السلة، رسالة ماجستير، كلية التزبية الرياضية

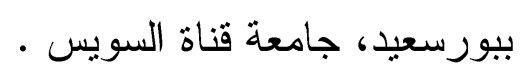
7. بسطويسي احمد بسطويسي : " سباقات المضمار ومسابقات الميدان " ، دار الفكر العربى ، بوريس . م) م99 ،

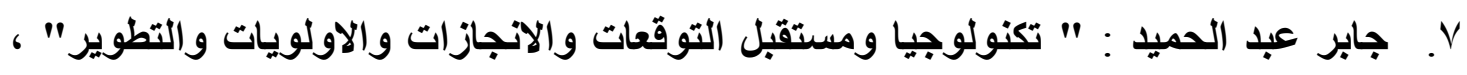
الجمعية المصرية لتكنولوجيا التعليم ، المجلد السادس ، سلسلة دراسات وبحوث تكنولوجيا

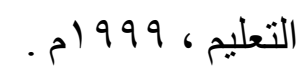
^. جابر عبدالحميد جابر (991 ام) : استراتيجية التدريس و التعلم"، مكتبة النهضة المصرية ، فالقاهرة

9. خالد مرجان عبدالايم (1997م): اثر استخدام بعض اساليب التعلم على مستوى الاداء فى القفز بالز انة للمبتدئين، رسالة دكتور اه، كلية التربية الرياضية للبنين، جامعة الزقازيق.

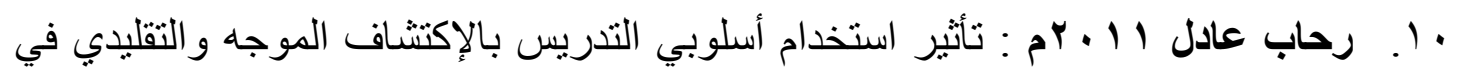
درس التربية الرياضية على بعض المهارات الحركية في كرة السلة لتلميذات المرحلة

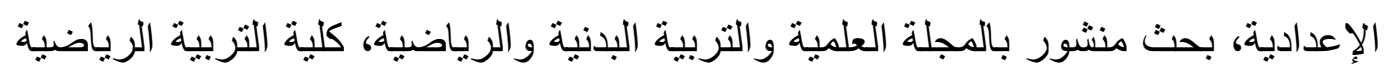

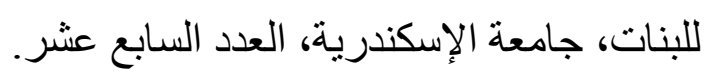

1ا. رشا محمد حسن حسين (10 • بم): تاثير برنامج التعليم الالكتونى المدمج عاى المتوى البدنى والرقمى لمسابقة دفع الجلة للمرحلة الابتدائية بدولة الامارات العربية المتحدة، رسالة ماجستير ، كلية التربية الرياضية للبنات، جامعة الزقازيق. r 1. زينب إسماعيل محمد (999 19): التدريس باسلوب الاكتشاف و اثره على اكتساب مهارة التصويب فى كرة اليد، رسالة دكتور اه، كلية التربية الرياضية، جامعة طنطا. ب ا. سعيد خليل الثاهد (99 (9 م): طرق تدريس التربية الرياضية، مكتبة الطلبة،القاهرة. 
ع ( سعيد خليل الثاهد : طرق تدريس التربية الرياضية ، مكتبة الطلبة ، شبرا ، القاهرة ،

1990

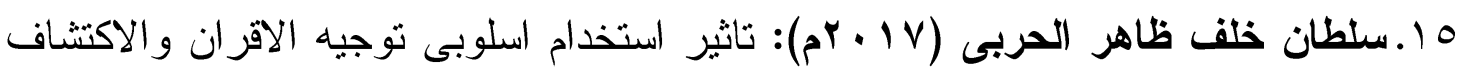
الموجه على مهار ات كرة اليد لتلاميذ المرحلة المتوسطة بدولة الكويت، رسالة ماجستير ، كلية التربية الرياضية بنين، جامعة الزقازيق. 4ا ا.طرق و اساليب التدريس فى التربية الرياضية، دار الوفاء للطباعة، الاسكندرية V V ا عبد الحميد شرف : البرامج في التربية الرياضية بين النظرية والتطبيق ، مركز الكتاب

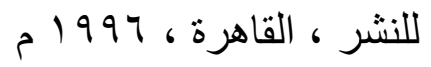
11. عبد الرحمن عبد الحميد زاهز : " فسيولوجيا مسابقات الوثب والقفز " ، مركز الكتاب

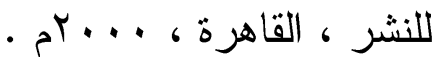

9 1. عفاف عبد الكريم حسن (ع 9 (م)): التنريس للتعلم فى التربية البدنية و الرياضية "اسليب استر اتيجيات - تقويم"، الطبعة الثانية، منشاة المعارف، الاسكندرية. •r. عفاف عبدالكريم حسن (•991م): التدريس للتعلم فى التربية الرياضية، اساليب استر اتيجية، تقويم، منشاة المعارف.

اY. على محمود الديرى († (91/م): مقارنة لفاعلية زمن الاداء الفعلى لدرس التربية الرياضية لكل من الطريقتن التقليدية والتبادلية ، مجلة بحوث التربية الرياضية، المجلد الثالث، العدد الخامس و السادس، كلية التزبية الرياضية للبنين، الزقازيق، اغسطس. r r. عويس الجبالى (919 (م): العاب القوى بين النظرية والنطبيق"،المكتب الاشتر اكى للالة

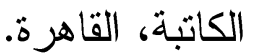

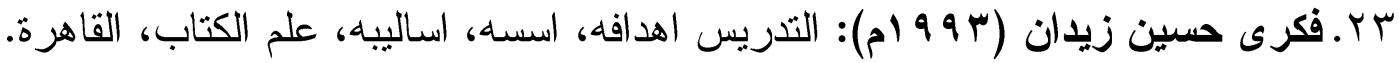

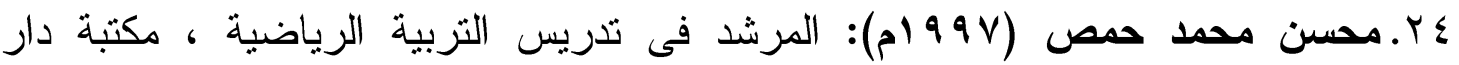

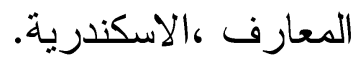

or. محمد ابراهيم شحاته ، محمد جابر بريقع : " دليل القياسات واختبارات الأداء الحركي " ،

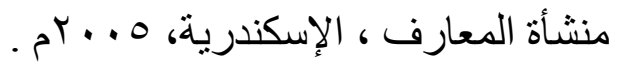

جr. محمد حسن علاوي ، محمد نصر الدين رضوان : " اختبارات الأداء الحركي " ، الطبعة

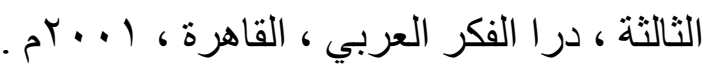


V V . محمد خميس أبو نمرة، نايف سعادة2009م : الثربية الرياضية وطر ائق تدريسها، الثركة

$$
\text { العربية المتحدة للتسويق و التوريدات، القاهرة، 9 ج. ب م. }
$$

^ץ. محمد صبحي حسانين : " القياس والتقويم في التربية البدنية والرياضة " ، الجزء الثاني

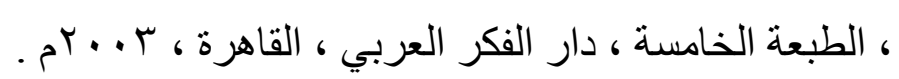

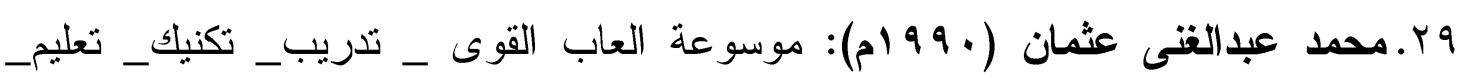

$$
\text { تحكم"، دار القلم للنشر و التوزيع، الكويت }
$$

• r. محمد عبدالغنى عثمان (ب99 (9)): التعلم الحركى والتدريب الرياضى، الطبعة الثالثة،

$$
\text { دار العلم، الكويت }
$$

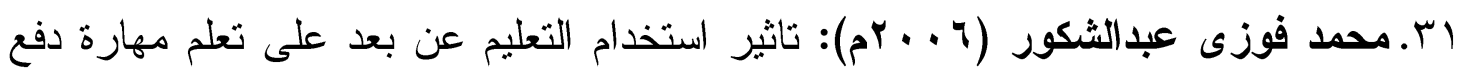
الجلة لطلبة كلية التزبية الرياضية،المجلة العلمية للتربية البدنية والرياضة، كلية التربية الرياضية للبنين، جامعة حلو ان.

rr. محمود داؤود الربيعى وسعيد صالح حمد امين (• ( •rم): الاتجاهات الحديثة فى تدريس التربية الرياضية، مطبعة منارة، اربيل.

سr. محمود يحيى سعد (9AVV) مهارة التصويب من الوثب فى رياضة كرة السلة، مجلة بحوث التزبية الرياضية، المجلد الر ابع، العدد السابع و الثامن، كلية التربية الرياضية بالزقازيق، جامعة الزبهة الزقازيق.

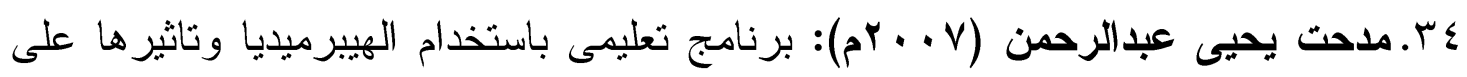
تعلم مسابقة دفع الجلة لاى طلبة المدارس الثانوية الفنية الصناعية، رسالة ماحستير، كلية التربية الرياضية للبنين، جامعة حلوان. هr.مديحة سامى ووفاء امين (799 (9)): المرجع فى مسابقات الميدان و المضمارللفتيات"، دار الكتاب للنشر ، القاهرة.

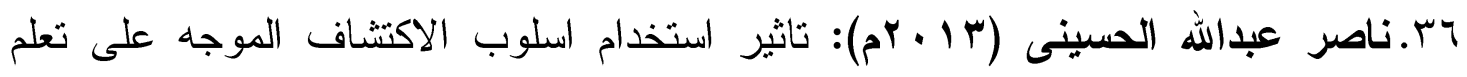
بعض مهارات العاب القوى للاطفال بدولة الكويت ، رسالة ماجستير، كلبة التربية الرياضية بنين، جامعة الزقازيق. 


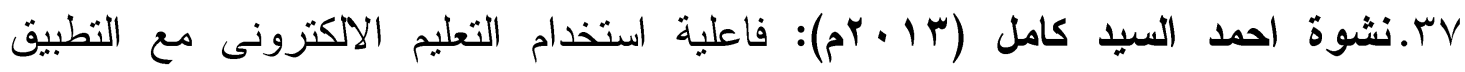
الميدانى لتعلم مسابقة اطاحة المطرقة لطالبات كلية التربية الرياضية للبنات بالزقازيق، رسالة ماجستير، كلية التربية الرياضية للبنات جامعة الزقازيق.

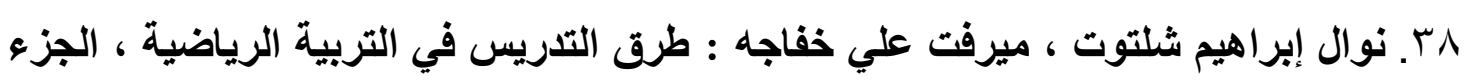

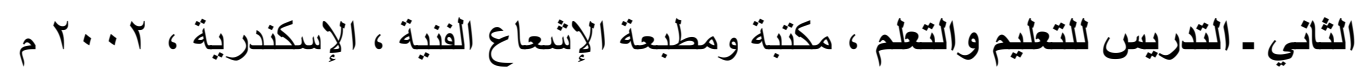

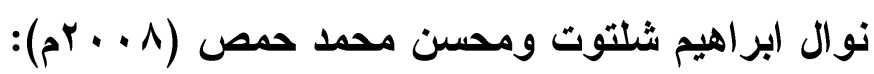
. $\mathrm{rq}$

طرق واساليب التدريس فى التزبية الرياضية، دار الوفاء للطباعة، الاسكندرية

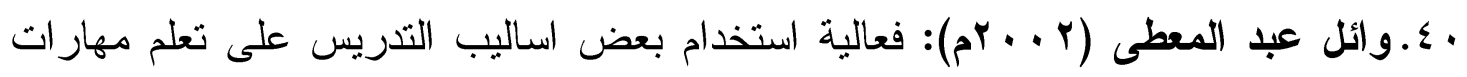

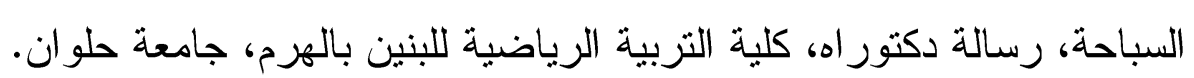

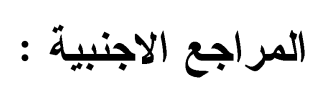

41-Mosston,Mand Teaching Physical Education, Thirded, Merrill Publishing Ashworth,Sera(1986): Company, Abell \& Howell Co, Columbus, London.

42-Shilling Mary Louy,E. the Effect of threesry for of teaching on University (2000): students sports performance.

Htt://ercirsysedu/pluels.cgi/ 